\title{
CINQUENTA ANOS DA CONVENÇÃO SOBRE A ELIMINAÇÃO DA DISCRIMINAÇÃO RACIAL: UMA APRECIAÇÃO CRÍTICA DE DENTRO
}

\author{
José A. Lindgren-Alves \\ é cônsul geral do Brasil em Barcelona e membro do Comitê para a Eliminação da Discriminação \\ Racial (CERD) da ONU. Barcelona. Espanha.E-mail: <lindgrenja@aol.com>
}

http://dx.doi.org/10.1590/ 0102-025082/100

Muito se falou em 2015 dos setenta anos das Nações Unidas, organização que proclamou a Declaração Universal dos Direitos Humanos três anos depois de sua criação. Poucos se lembraram de que em 2015 transcorria também o cinquentenário do primeiro tratado de direitos humanos: a Convenção sobre a Eliminação de todas as Formas de Discriminação Racial. As razões desse "esquecimento" podem ter sido diversas. Pela ótica do direito, nenhuma se justifica diante do fato de que essa Convenção, de 1965, em paralelo a seu valor intrínseco, foi o instrumento inaugural do Direito Internacional dos Direitos Humanos ${ }^{1}$.

Sem contar breve mensagem emitida em Nova York, em 21 de dezembro, pelo Secretário Geral Ban Ki-moon, na passagem do aniversário da adoção da Convenção pela Assembleia Geral, ou possíveis comemorações localizadas

\footnotetext{
1 A Convenção contra o Genocídio é de 1948, mesmo ano da Declaração Universal. Trata de matéria aberrante e raramente chega a ser citada entre os instrumentos do Direito Internacional dos Direitos Humanos. Estes se dirigem essencialmente ao dia a dia de sociedades que se desejam democráticas, procurando regular a área em questão.
} 
sem repercussão no exterior, a principal celebração ocorreu em Genebra, por iniciativa do órgão previsto pelo próprio instrumento para acompanhar sua aplicação: o Comitê para a Eliminação da Discriminação Racial (CERD, sua sigla em inglês). Integrado, de acordo com o artigo $8^{\circ}$, por dezoito "peritos imparciais" de diversas regiões, "formas de civilização" e sistemas jurídicos, eleitos pelos Estados-partes para mandatos de quatro anos, o CERD se estabeleceu em 1970, com a posse dos primeiros membros. Aos 45 anos de idade em 2015, e com composição muitas vezes renovada, ele constitui o mais antigo "órgão de tratado", tendo servido de modelo para os demais.

A celebração do cinquentenário da Convenção de 1965 em Genebra transcorreu em duas sessões especiais do $88^{\circ}$ período de sessões regulares do CERD, na manhã e na tarde de 26 de novembro. Desenvolveu-se em dois painéis sucessivos, integrados por personalidades convidadas. $\mathrm{O}$ 26 primeiro painel tinha por tema "Cinquenta anos de realizações - lições aprendidas e boas práticas"; o segundo, "Desafios atuais e caminhos para prosseguir”. As exposições eram seguidas de intervenções do "público" credenciado: Estados e organizações não governamentais de diversas procedências, quase todas dedicadas à promoção de minorias étnicas ou ligadas ao movimento negro norte-americano.

Os painéis foram expressivos como manifestação de apoio político à Convenção de 1965 depois de meio século. Desde o início, porém, o evento teve aparência deslocada no tempo e no espaço. Somente treze dias após o pior ataque terrorista em Paris, com 130 mortes e centenas de feridos em café e casa de espetáculos, a comemoração no Palácio das Nações genebrino parecia, no mínimo, inoportuna. Apesar da preocupação geral com a possibilidade de novas ações terroristas, observada desde logo no reforço dos sistemas de segurança da ONU e da Suíça, nenhum dos oradores registrados falou da tragédia que acabara de ocorrer 
ali ao lado, ou de massacres semelhantes na mesma época alhures. Tampouco se falou do extremismo suicida e da atração que ele exerce no mundo contemporâneo.

Não digo que o aniversário da Convenção devesse ser lúgubre, nem fantasio que esse tratado ou seu Comitê possa oferecer solução para conflitos desencadeados. Ou sirva para resolver problemas sistêmicos disseminados no planeta. O CERD não tem competência legal para lidar com guerras, nem meios para combater com eficácia vicissitudes onipresentes, causadoras de discriminações. A inconsequência política, a corrupção, as disparidades econômicas gigantescas, a leviandade dos meios de comunicação, a facilidade para a divulgação de propaganda odiosa são aspectos comuns de nossa fase, tecnologicamente avançada e autodestrutiva, que requerem anteparos e correções consistentes. Por mais que, algumas vezes, diante de perspectivas preocupantes, o Comitê tenha procurado alertar para os efeitos discriminatórios de decisões ominosas e omissões graves dos Estados-partes em esferas que ultrapassam a letra - não o espírito - da Convenção de $1965^{2}$, dele não se espera mais do que ação simbólica. Os símbolos, contudo, quando pertinentes, não devem ser evitados. Eles são particularmente importantes na área internacional dos direitos humanos, onde o que sempre prevaleceu de melhor nunca passou de pressão moral. E símbolos das preocupações gerais mais prementes fizeram falta na comemoração em 2015.

Apesar dessa falha sensível, o seminário propiciou uma visão abrangente dos trabalhos do CERD. O que este texto

2 A título de exemplo, recordo a Declaração de 10 de março de 2003 (Statement on the current international situation), antes da invasão do Iraque pelos Estados Unidos, que advertia para os "efeitos devastadores também no recrudescimento dos fenômenos da discriminação racial ou étnica, da xenofobia, da intolerância e até do terrorismo" da operação prestes a iniciar-se. Assim como a Decisão de 22 de agosto de 2014, diante da passividade geral em face dos atos genocidas do Estado Islâmico do Levante (ISIL ou ISIS), então concentrados no Iraque (Iraq-Decision 1, da $85^{\mathrm{a}}$ sessão). 
pretende é, a partir de alocuções escolhidas, apontar virtudes e defeitos desse órgão do sistema internacional. Simultaneamente reflexo e fonte do discurso dominante em cada ocasião, a atuação do Comitê necessita ser conhecida, e suas distorções, reparadas. Especialmente se ainda prevalecer entre os atores influentes, governamentais e não governamentais, alguma intenção de recolocar os direitos humanos na posição simbólica diretiva que tiveram há vinte anos para a esfera social ${ }^{3}$.

\section{Introdução aos trabalhos: a variedade da família humana}

Nas funções de presidente do CERD durante o biênio 201415, o membro guatemalteco, José Francisco Cali Tzay, indígena maia aguerridamente orgulhoso da identidade nativa, deu início aos trabalhos. Recordou que, no decorrer dos cinquenta anos da Convenção, o mundo assistiu a avanços notáveis, como a vitória do movimento pelos direitos civis 28 nos Estados Unidos e o fim do regime de apartheid na África do Sul. Assinalou que, sendo o combate ao racismo tarefa plurifacetada, o CERD fornece recomendações aos Estados-partes, mas não pode sozinho eliminar as discriminações. Para isso, é necessária uma multiplicidade de atores, aí incluídos governos, instituições nacionais independentes e a sociedade civil. Registrou a necessidade de se prosseguir na conscientização de que a família humana é uma única, com culturas e línguas variadas, acrescentando que a diversidade deve ser reconhecida e protegida ${ }^{4}$.

Militante da causa indígena internacionalmente conhecido, Cali Tzay, que já se distinguia desde o ano anterior na presidência do Comitê, fez introdução equilibrada, que

\footnotetext{
3 Escrevi bastante sobre esse assunto, em particular no livro Relações internacionais e temas sociais: a década das conferências (Lindgren-Alves, 2001).

4 Os resumos da fala de Cali Tzay e de todos os demais foram feitos a partir de anotações minhas e de material divulgado pelo Escritório do Alto Comissário das Nações Unidas para Direitos Humanos, em sua página na internet: <www.ohchr.org $>$.
} 
dispensaria contextualização. A não ser pela afirmação final de que a diversidade cultural precisa ser protegida, entendimento típico da fase contemporânea.

Hoje dada como inquestionável e aceita verbalmente pelas sociedades ditas civilizadas, a proteção das identidades específicas, nos primeiros anos de vigência da Convenção de 1965, não era vista como necessária pela maioria dos ativistas sociais. Conquanto facções radicais do movimento negro norte-americano, como a "Nação do Islã", de Elijah Muhammad, Malcolm X (filho de simpatizantes do Pan-Africanismo do jamaicano Marcus Garvey, violentamente perseguidos), ou o pugilista Cassius Clay (convertido em Muhammad Ali e transformado em gigante simbólico da africanidade) postulassem a autoafirmação dos negros como comunidade distinta, inassimilável, optando pelo islã como religião não branca, essa asserção não era predominante. O objetivo das lideranças mais influentes era a superação das diferenças. O célebre "sonho" de Martin Luther King, explicitado na histórica Marcha sobre Washington de 1963, consistia num país igualitário, onde as pessoas fossem avaliadas pelo mérito individual, não pela cor. Ou seja, o principal líder negro dos Estados Unidos, pastor protestante universalista, desejava uma meritocracia abrangente e justa, não excludente, em seu Estado nacional. Tal como era abrangente e igualitária a luta antissegregacionista de Nelson Mandela, já preso na África do $\mathrm{Sul}^{5}$. Embora o igualitarismo tenha prevalecido nas leis antissegregacionistas, o diferencialismo afro-americano altivo como "força revolucionária" de oposição ao establishment foi a vertente encampada pelos jovens contestatários das décadas de 1960 e 70, negros e brancos, firmando-se na academia até hoje.

5 O Congresso Nacional Africano (ANC), seu partido, além de incluir brancos militantes contrários ao apartheid, tinha originalmente inclinação socialista, de linha marxista. 
Não foi, porém, o pan-africanismo do movimento negro que transferiu o enfoque do CERD e das Nações Unidas do universalismo dos direitos humanos para o particularismo cultural das comunidades étnicas. Foi a movimentação dos indígenas das Américas - em que se inseriu Cali Tzay como maia - pela asserção de direitos próprios específicos. Mas isso levou muitos anos.

Iniciada também nos Estados Unidos dos anos 1960, em paralelo ao movimento negro e ao feminismo do women's lib, a autoafirmação dos "nativos" da América do Norte como identidade diferente da "americana" refletiu e fortaleceu o africanismo ideológico, não necessariamente violento, dentro do movimento negro. Estendeu-se a outros setores da população como os "hispânicos", ampliando-se no país e no exterior, abrangendo comunidades minoritárias. A luta inicial, contudo, era pelo reconhecimento dos direitos individuais de todos em condições de igualdade com a maioria. 30 Somente na década de 1990, a afirmação das diferenças culturais como necessidade coletiva, a ser protegida e estimulada em todos os Estados, atingiria o nível de exigência indispensável à plena realização das pessoas.

Embora em 2015, naquela mesma celebração em Genebra, alguns oradores e ONGs já tenham posto em dúvida a "vitória do movimento pelos direitos civis" nos Estados Unidos, à luz de incidentes policiais fatais com repercussões nacionais, e por mais que a "defesa da identidade cultural" já fosse utilizada contra imigrantes, a alocução de Cali Tzay na abertura dos trabalhos poderia ser subscrita por qualquer membro do CERD. Preferencialmente, para mim, com algum gesto de solidariedade com os alvos imediatos de atentados, de repúdio a todos os tipos de terrorismo, de preocupação com os novos fluxos maciços de migrantes, incluindo famílias inteiras foragidas em busca de asilo, vítimas patéticas e atualíssimas de múltiplas discriminações. 


\section{Primeiro Painel: Cinquenta anos de realizações - Lições aprendidas e boas práticas}

A primeira exposição do painel da manhã coube ao acadêmico britânico Patrick Thornberry, que havia integrado o CERD de 2002 a 2014 e foi, possivelmente, o membro mais influente no estabelecimento das prioridades hoje vigentes. Sua primeira alocução e seus comentários posteriores abordaram tópicos importantes para o entendimento da Convenção e do funcionamento do Comitê.

\section{Colonialismo e apartheid}

Participando do evento como convidado, Thornberry fez apanhado histórico, lembrando que a Convenção havia sido elaborada em conjunção com os processos de descolonização e luta contra o apartheid. Recordou as antigas teorias de superioridade racial, historicamente identificadas com o colonialismo, destacando nesse contexto a construção de identidades nacionais como fator importante para o combate ao racismo. Recordou a "desconstrução" do conceito de raça pela Unesco, acrescentando, porém, que, com incidências diferentes, o fenômeno das discriminações é ubíquo. Singularizou a emergência do ativismo indígena, o fim do regime de apartheid e a realização de conferências contra o racismo como fatores de conscientização. Apontou as Observações gerais - antes Recomendações gerais - como mecanismo de interpretação e atualização da Convenção de 1965 utilizado pelo CERD, destinadas a orientar todos os Estados-partes sobre o assunto abordado, e salientou a importância que o Comitê confere à educação para a erradicação do racismo.

Dessa exposição de Thornberry, anotei em particular sua afirmação de que "a discriminação racial não é alheia a qualquer área do mundo". A consciência desse fato, hoje quase universalizada, parece-me representar a mais importante conquista do CERD desde os primeiros passos para o avanço dos esforços contra a discriminação racial em qualquer fase. 


\section{O racismo como fenômeno planetário}

Nos anos 1970, quando o Comitê começou a funcionar, a campanha internacional contra o regime segregacionista sul-africano encontrava-se no auge. Ligado ao colonialismo do passado e mantido pela dominação sul-africana na África do Sudoeste - atual Namíbia -, além de influente na Rodésia de Ian Smith - atual Zimbábue -, o apartheid, sob o disfarce de "desenvolvimento separado", era o meio "legal" pelo qual o elemento branco da África do Sul "colonizava" os coabitantes negros, transformando-os em estrangeiros em sua própria terra, não cidadãos, sem direitos ou com direitos discriminatoriamente limitados. Em função dessa anomalia político-jurídica condenada pela ONU, o apartheid constitucional funcionava não apenas como alvo prioritário, mas como "abscesso de fixação" na luta internacional contra o racismo. Grande parte dos primeiros Estados subscritores da Convenção de 1965 - entre os quais o Brasil 32 do regime militar - ratificou esse instrumento no entendimento de que a discriminação racial era um problema de outros: uma questão excepcional, de situações específicas, como as da África Austral ou dos Estados Unidos, vistas como casos isolados ${ }^{6}$. Ao apresentar os relatórios periódicos ao Comitê, previstos no artigo $9^{\circ}$ da Convenção, muitos dos Estados-partes diziam que, sendo constitucionalmente igualitários, sem segregações estipuladas em lei, não havia discriminações nas respectivas jurisdições. Não necessitariam, portanto, adotar novas medidas para seguir a Convenção.

O CERD, desde o início, rejeitou tais afirmações, insistindo na probabilidade de ocorrência de práticas ou atos discriminatórios disfarçados que também precisam ser

\footnotetext{
6 Não é de estranhar que somente após o fim do regime segregacionista, a África do Sul tenha-se tornado parte da Convenção, que assinou em 1994 e ratificou em 1998. Os Estados Unidos assinaram-na em 1966, mas somente a ratificaram em 1992, na onda de incentivo aos direitos humanos dos primeiros tempos pós-Guerra Fria e preparação para a Conferência de Viena.
} 
combatidos. Hoje são raríssimos os Estados que insistem na inexistência de racismo em território nacional ${ }^{7}$. Quando o fazem, quase sempre atribuem tal virtude intrínseca à religião respectiva, ou, em casos crescentemente anacrônicos, à homogeneidade da população. Todos são invariavelmente repreendidos pelos peritos, que lhes recordam a responsabilidade internacional dos Estados para a erradicação do racismo, ainda que na esfera privada e em manifestações isoladas à revelia do governo. Embora não haja disposição convencional clara nesse sentido, os peritos juristas tendem a considerar imprescindível a proibição, expressa por lei, da discriminação racial na definição dada pelo artigo $1^{\circ}$ da Convenção (baseada em raça, cor, descendência, origem nacional ou étnica). Tampouco aceitam a ausência de queixas ou ações judiciais como comprovação da inexistência de racismo, pois ela poderia advir da falta de legislação adequada, da inaplicabilidade da Convenção pela Justiça nacional, do desconhecimento de seus direitos pelas vítimas, ou, até, do temor de retaliações.

\section{Classificações, estatísticas e medidas especiais}

Mais tarde, em intervenção nas considerações finais do primeiro painel, o professor Thornberry sublinhou a importância que o CERD confere à apresentação de dados estatísticos sociais e econômicos desagregados por categorias populacionais - ou, como se tem dito, por "etnias" - como instrumental necessário para aferir o grau de igualdade ou discriminação entre elas. Observou, a propósito, que alguns Estados têm reservas práticas ou ideológicas ao levantamento de informações sobre etnia e religião, especialmente entre imigrantes. Acrescentou que o CERD tem orientado os

\footnotetext{
7 Apesar da diferença semântica entre "racismo", preconceito ou ideologia, e "discriminação racial", diferenciação que impõe separações, emprego aqui indistintamente os dois termos, porque é assim que age o CERD e a maioria dos Estados.
} 
Estados contrários a tal apuração a utilizarem fontes alternativas de informação, como pesquisas acadêmicas ou levantamentos de ONGs, que indiquem numericamente a situação das diferentes categorias.

A classificação das populações por categorias ou "raças" em sistemas taxonômicos considerados científicos, até meados do século XX, tendia a criar hierarquias que, em princípio, "naturalizavam" a estratificação doméstica e internacional, com base na qual se justificariam, sem necessidade de recorrer à religião, tanto o escravismo, quanto o colonialismo, sendo este decorrência da "missão civilizadora do homem branco". A partir dos Estados Unidos nos anos 1960, a velha classificação racial por cor ou origem étnica, que vinha do regime escravista e sobreviveu à Guerra de Secessão, passou a ser a base para distribuição de recursos sociais e para a fixação de quotas e outras formas de "ação afirmativa".

Nesse sentido positivo, as classificações por categorias 34 podem realmente ser úteis, conquanto não essenciais, para comparações estatísticas e para a adoção das "medidas especiais" previstas no artigo $1^{\circ}$, parágrafo $4^{\circ}$, e artigo $2^{\circ}$, parágrafo $2^{\circ}$, da Convenção. De caráter necessariamente temporário, em favor de grupos raciais ou étnicos que se encontrem em situação de inferioridade real, as medidas especiais no texto convencional visam superar o chamado "racismo estrutural”, que não acompanha a igualdade legal. Esse é o fundamento das posições do CERD na matéria, seguidas por militantes dos direitos específicos de todas as minorias. Além disso, considera-se que a rejeição às classificações e às estatísticas desagregadas tende a encobrir o racismo não assumido dos segmentos dominantes.

Embora não reflitam todas as situações, esses argumentos podem ser válidos. Há alguns Estados que ainda se recusam a apresentar informações sobre etnias diferentes, insistindo na inexistência de grupos raciais ou étnicos minoritários em sua população. Por outro lado, é importante notar que os maiores 
opositores das classificações e divisões estatísticas atualmente não são governos arbitrários, ocultadores do racismo sob um manto de miscigenação - se é que a miscigenação alguma vez serviu realmente de ocultação para qualquer fato. A própria França, precursora do republicanismo igualitário - ainda que historicamente excludente das mulheres - desde a Revolução de 1789, não reconhece minorias, mas não hesita em declarar-se demograficamente multicultural. Quem mais resiste, por necessidade inteligível, às classificações e estatísticas desagregadas são os Estados africanos, oriundos da descolonização. Estes, ainda em processo de construção da respectiva nacionalidade, com graves problemas econômicos, democratização tardia e, em certos casos, heranças do apartheid ou enfrentamento do terrorismo "jihadista", pressentem os riscos de exacerbar, com levantamentos sobre religião e etnia, antagonismos tribais ou facciosos. Em geral, eles não negam a existência de grupos variados em seu seio, adotando, inclusive, políticas específicas para ajudar os vulneráveis.

A mesma lógica, com as adaptações necessárias, leva hoje países como a Alemanha, a Suécia, a Bélgica, Portugal e a Espanha a não fazerem tal levantamento. Não o fazem, oficialmente, em nome dos direitos individuais à privacidade e à liberdade de religião, mas também por temerem que a identificação classificatória propicie maior rejeição a eles e estímulo a crispações comunitárias. O máximo que tais Estados europeus apresentam - justificadamente, creio eu - nos relatórios ao CERD são números globais de imigrantes por nacionalidade, ou estimativas extraoficiais para grupos específicos, como os roma ou ciganos, em suas diversas autodenominações ${ }^{8}$.

\footnotetext{
8 Roma é autoidentificação na Europa Central e Oriental, generalizada por terceiros. A explicação me foi dada por ciganos da Inglaterra, no CERD, que se chamam gypsies. A palavra gypsy parecer vir de Egyptian - em português "egípcio" ou "egipcíaco", autodesignação de certos grupos nos Bálcãs, que gera confusões com o gentílico da república árabe. Na Península Ibérica, os gitanos da Andaluzia e os ciganos de Portugal são reconhecidos como formadores importantes da respectiva cultura nacional.
} 
As estatísticas desagregadas, objeto de antiga Recomendação Geral e orientação para os relatórios periódicos, são, portanto, matéria não consensual, compreensivelmente controversa, que não deveria ser imposta como obrigação a todos. Conforme tenho sempre recordado aos colegas, especialmente quando lidamos com países africanos, obrigatória é a Convenção, jus cogens para todos Estados-partes, não a maneira de aplicá-la às diferentes circunstâncias. A sensibilidade especial na África e em muitos países da Ásia para divisões censitárias, para não falar dos aspectos contraproducentes das identificações étnicas em países da Europa e outros, é algo que os movimentos negros e as lideranças de minorias étnicas, bem como as ONGs atuantes junto aos peritos deveriam levar em consideração. Afinal, como provam exemplos de todas as regiões, inclusive com relação a imigrantes, elas não são essenciais sequer para a adoção de medidas especiais.

\section{O tema contemporâneo do racismo, xenofobia e intolerância correlata}

O segundo expositor do painel matinal foi o Relator Especial das Nações Unidas sobre Formas Contemporâneas de Racismo, Discriminação Racial, Xenofobia e Intolerância Correlata, mecanismo não convencional de monitoramento criado pela antiga Comissão dos Direitos Humanos para acompanhar esse tema onde quer que ocorra. A função é atualmente exercida pelo advogado Mutuma Ruteere, de origem queniana.

Em decorrência da confusão que ainda se faz entre as funções desse relator "temático", estabelecido por simples resolução de órgão político da $\mathrm{ONU}^{9}$, e as do Comitê para a Eliminação da Discriminação Racial, órgão permanente de

\footnotetext{
9 Resolução 1993/20, da Comissão - hoje Conselho - dos Direitos Humanos, renovada anualmente.
} 
instrumento jurídico ratificado pelos Estados-partes, o relator adotou postura apologética, quase humilde. Afirmou que o CERD, nos seus 45 anos de existência, tem abordado de maneira eficaz todas as questões emergentes, adotando práticas adequadas. Entretanto, como a Convenção não conta com ratificação universal, os Estados-partes atrasam na submissão de seus informes e revelam limitações no cumprimento das recomendações recebidas, seu mandato de relator especial, abrangente e flexível, permite-lhe complementar o trabalho. Mencionou, nessa linha, a título de ilustração, as cobranças que faz sobre recomendações do Comitê nos países por ele visitados. Citou o caso da República da Coreia, em 2012, indagada sobre o mecanismo de controle independente dos meios de comunicação recomendado pelo CERD contra a propagação de noções de superioridade racial e ódio aos estrangeiros, tendo sido informado de oito emissoras de televisão que retiraram programas com conteúdo desse tipo. Em visita à Mauritânia, em 2013, o relator verificou igualmente que o Estado havia adotado, conforme recomendação do CERD, legislação contra todas as formas de discriminação previstas no artigo $1^{\circ}$ da Convenção. Em contraposição aos esforços observados, Ruteere aludiu por alto aos "surtos recentes de violência que resultam em movimentos da população a exigir novos compromissos dos Estados para garantir os direitos dos refugiados e migrantes", notando que "velhos problemas de racismo e discriminação persistem". Advertiu, também, moderada e oportunamente, sobre o discurso racista utilizado por partidos políticos populistas para mobilizar apoio eleitoral em determinados países.

É verdade que o recurso da antiga Comissão dos Direitos Humanos à figura de um relator especial para o racismo, a xenofobia e novas formas de intolerância em 1993, mantido pelo atual Conselho, visava cobrir o déficit de acompanhamento do assunto pela ONU. Havia, porém, outros 
motivos, aflitivos, que levavam a velha Comissão a criar algo novo na década de 1990, como símbolo de preocupação, ou como catarse. Algumas razões para o estabelecimento dessa relatoria temática eram dificuldades de ordem institucional, da ONU e da Convenção, aludidas indiretamente pelo orador: a impossibilidade prática de atuação do CERD fora dos períodos de sessão, o custo imprevisível de convocações extemporâneas, a limitação do mandato definido nos artigos $8^{\circ}$ e $9^{\circ}$, voltado para países que apresentavam - ou deveriam apresentar - relatórios. Predominava, porém, sobretudo, na Comissão dos Direitos Humanos e demais órgãos, a pressão da opinião pública, perplexa com a passividade internacional perante os conflitos emergentes desde o fim da Guerra Fria e da União Soviética, com base étnica e componente religioso. Dentre eles, ressaltavam a fragmentação bélica do Cáucaso e da antiga Iugoslávia, os massacres de bósnios "muçulmanos" por "cristãos" sérvios, mostrados na 38 televisão, a exacerbação de tensões entre hutus e tutsis em Ruanda e no Burundi, o extremismo do FIS (Front Islamique do Salut) na Argélia - precursor das brutalidades do ISIS no Magreb e do terrorismo "jihadista” na França.

Vem também dessa época, com as mesmas preocupações, o pedido, decorrente da ideia de diplomacia preventiva do então Secretário Geral Boutros-Ghali ${ }^{10}$ de que o CERD, como órgão do sistema, examinasse situações excepcionais com tendência de evolução para o genocídio, origem do "procedimento de alerta e ação urgente" ainda existente. Foram igualmente essas e outras motivações assemelhadas que levaram à primeira proposta no âmbito da ONU, em 1994, para a realização de "uma conferência mundial contra

${ }_{10}$ An agenda for peace: preventive diplomacy, peacemaking and peacekeeping (doc. A/47/277 - S/24111, 17/6/1992), texto de grande repercussão, previa a mobilização de todo o sistema das Nações Unidas para a identificação de fontes graves de tensões para atuação antes que degenerassem em conflitos (daí early warning ou "alerta que venha cedo, tempestiva"). 
o racismo, a discriminação racial ou étnica, a xenofobia e outras formas contemporâneas correlatas de intolerância"11, que viria a ser a Conferência de Durban de 2001.

\section{O tema contemporâneo das minorias}

Enquanto a exposição do Relator sobre Formas Contemporâneas de Racismo dispensa maiores considerações, a exposição seguinte, da Relatora Especial para Questões de Minorias, a cidadã húngara de origem roma Rita Izsák, pede comentários. Até porque se trata de função e mandato relativamente novos.

Conforme assinalado pela própria relatora, seu "tema" de direitos humanos não era previsto no mandato do CERD. De fato, como ela própria observou na cerimônia, o vocábulo "minorias" não é sequer mencionado na Convenção de 1965. Nem - acrescento eu agora - na Declaração Universal de Direitos Humanos, de 1948. Ou nos dois pactos que regulamentaram a Declaração com instrumentos jurídicos, em 1966.

Conquanto a questão das minorias nacionais na jurisdição de outro Estado tivesse sido discutida nos trabalhos preparatórios da Declaração Universal, nos anos 1940, optara-se propositalmente pela omissão do vocábulo. Afinal, as "minorias alemãs" em território tcheco haviam servido de pretexto para a primeira invasão nazista, decorrente dos Acordos de Munique de 1938. Além disso, não havia uma definição internacional aceita para o conceito de "minoria". Como não há até hoje. O que tem ocorrido atualmente é a utilização abundante do vocábulo sem definição jurídica, adjetivado por outro conceito delimitador, como "minoria cultural", "minoria étnica", "minoria religiosa", "minoria linguística” e assim por diante.

\footnotetext{
${ }^{11}$ Resolução 1994/2 da Subcomissão para a Prevenção da Discriminação e Proteção de Minorias, hoje extinta. Descrevi mais atentamente a motivação dessa resolução fundamental e a própria Conferência de Durban em Os direitos humanos na pós-modernidade (Lindgren-Alves, 2005, pp. 113-40).
} 
Em paralelo às dificuldades políticas, a doutrina jurídica dominante, contra a vontade dos indígenas, do Terceiro Mundo "em desenvolvimento" e a ideologia dos países do bloco comunista, os direitos humanos sempre foram vistos como direitos individuais, das pessoas, não de grupos ou coletividades. A exceção era do direito à autodeterminação dos povos, de titularidade intrinsecamente coletiva, não constante da Declaração Universal em 1948, mas reconhecido no artigo $1^{\circ}$ dos dois pactos de 1966. Advindo no contexto do movimento internacional pela descolonização, ele representou um apoio discursivo importante à luta pela independência das colônias com relação às metrópoles, embora não fosse seriamente encarado como um "direito", muito menos "humano". A ele se iria associar, mais tarde, o direito ao desenvolvimento, também coletivo, mas não "justiciável”, passível de ser cobrado em juízo. Ambos foram aceitos consensualmente, depois de muitas resistências, 40 pela primeira vez, na Declaração de Viena sobre Direitos Humanos, da Conferência Mundial de 1993 (artigos $2^{\circ} \mathrm{e}$ $10^{\circ}$ dessa declaração) $)^{12}$. A interpretação predominante para sua aceitação pelos Estados líderes do Ocidente era de que esses chamados "direitos de terceira geração", que atualmente proliferam, como o "direito ao meio ambiente", o "direito à paz" e outros, de titularidade mais do que coletiva, geral e indefinida, seriam importantes para a realização dos direitos individuais de todos ${ }^{13}$.

Por mais que a ONU achasse, desde cedo, que as minorias devessem ser protegidas, como demonstra o nome da hoje extinta Subcomissão para a Prevenção da Discriminação e Proteção às Minorias, principal órgão subsidiário da

\footnotetext{
12 As ressalvas e motivações para a aceitação consensual desses direitos coletivos acham-se explicitadas no meu livro Os direitos humanos como tema global (Lindgren-Alves, 2011).

${ }^{13}$ Não incluo aqui o controvertido "direito de ingerência", mas sim o direito, individual e coletivo, de receber assistência humanitária.
} 
antiga Comissão dos Direitos Humanos, a ênfase sempre foi maior no igualitarismo dos direitos fundamentais do que nas particularidades das culturas, no universalismo do indivíduo do que no relativismo dos valores essenciais. Foi com tal entendimento que se construíram as bases do sistema internacional de promoção e proteção aos direitos humanos até meados da década de 1990. A ideia "pós-moderna" de que as pessoas somente se assumem de maneira autêntica no quadro das respectivas culturas passou a predominar mais recentemente. Dentro das Nações Unidas, o ponto de inflexão deu-se pela adoção da Declaração dos Direitos das Pessoas Pertencentes a Minorias Religiosas ou Linguísticas, enganosamente chamada de "Declaração dos Direitos das Minorias", de $1992^{14}$.

Quando a antiga Comissão dos Direitos Humanos decidiu, em 2005, criar um mecanismo - na linguagem do Secretariado um "procedimento especial" - para promover a observância dessa declaração em todo o mundo, a resolução pertinente foi tomada dentro de item da agenda dedicado aos "Direitos das Pessoas Pertencentes a Minorias Religiosas ou Linguísticas". ${ }^{15}$ Não obstante, ao solicitar ao Alto Comissário das Nações Unidas para Direitos Humanos a designação de representante especial para o tema, a resolução já falava, de forma aparentemente simplificada, em "questões de minorias" (minority issues). ${ }^{16}$ Tal imprecisão, com objetivos variados, permitia expandir o mandato do relator proposto, transferindo o foco e a titularidade dos direitos humanos dos integrantes de um grupo ou categoria para o conjunto respectivo. A quem porventura suponha que a diferença é pequena, lembro, contrario sensu, que, pela ótica dos direitos individuais, da Declaração Universal dos Direitos Humanos, os integrantes de um grupo têm o

\footnotetext{
${ }^{14}$ Resolução 47/137, da Assembleia Geral.

${ }^{15}$ Resolução 2005/79 da Comissão dos Direitos Humanos.

${ }^{16}$ Resolução 2005/79 da Comissão dos Direitos Humanos, parágrafo 6 com alíneas.
} 
direito de sair dele; os seguidores de uma religião têm liberdade para converter-se ou simplesmente deixá-la; os integrantes de uma cultura têm a opção legítima de assimilar-se a outra. Pela ótica coletiva dos grupos, religião ou cultura em sentido étnico, ocorre quase sempre o contrário.

Nas palavras da Relatora Rita Izsák durante a comemoração de 2015, a omissão do termo "minoria" na Convenção de 1965 não tem impedido que o CERD adote um enfoque mais amplo para a execução de seu mandato contra a discriminação racial, "examinando os direitos das minorias consagrados na Declaração das Nações Unidas sobre Minorias [sic], inclusive a proteção de sua existência, a promoção e proteção das identidades minoritárias ou o direito à participação em todas as esferas da vida". Embora a expositora tenha repetido, talvez até inadvertidamente, a omissão, prenhe de consequências, na referência à Declaração de 1992, base de seu mandato, é verdade que o CERD tem agido como ela diz. Como é correta sua 42 afirmação seguinte, de que o Comitê "também encontrou um caminho para abranger as violações dos direitos das minorias linguísticas ou religiosas [...] desconsiderados no discurso do racismo"17. Para fazê-lo, sem necessitar de emendas ao texto da Convenção, o CERD se fundamenta na "origem étnica", registrada juntamente com a origem nacional no artigo $1^{\circ}$, entre as causas dos atos e omissões que configuram discriminação racial. Daí, partindo do pressuposto de que a língua e a religião são elementos formadores das etnias, trata regularmente de tais questões. A abordagem é pouco objetada pelos Estados-partes, a não ser para a defesa de tradições arraigadas e posturas religiosas inspiradas por dogmas.

Tão ou mais importante do que as opiniões da simpática e batalhadora Rita Izsák sobre a Convenção e o CERD foi

\footnotetext{
${ }^{17}$ A intervenção de Rita Izsak, em inglês, pode ser lida nas contributions publicadas em: <http://www.ohchr.org/EN/HRBodies/CERD/50/Pages/Icerd50.aspx>. O tema das minorias, de grande atualidade e efeitos controversos, merece análise aprofundada, que ultrapassa os objetivos deste texto.
} 
sua declaração inicial de que vinha falar "não apenas como Relatora sobre Minorias [sic], mas também como mulher roma, que tem lutado pelos direitos dos roma, especialmente das mulheres roma", motivada por sua experiência pessoal pregressa, despedida de emprego quando o patrão "descobriu" sua origem. Daí seu louvor especial às recomendações do Comitê sobre o direito das minorias à cultura própria e sua informação de que utiliza observações do Comitê, singularizando as Recomendações Gerais n ${ }^{\circ} 27$ (de 2000), sobre a discriminação contra os roma, e n 35 (de 2013), de combate ao discurso do ódio racial nos meios de comunicação. De fato, a partir dessas e de outras recomendações gerais, o CERD trata atualmente da proteção de minorias étnicas e, como ele próprio marca, "etnorreligiosas", de maneira quase obsessiva. Retransmitindo as cobranças de praticamente todas as ONGs defensoras de minorias culturais, o Comitê exige seu reconhecimento formal pelos Estados examinados, juntamente com medidas especiais e aplicação de estratégias à sua promoção.

A possibilidade de assumir a identidade de origem é um aspecto inerente à dignidade humana, premissa da igualdade de todos no gozo das liberdades fundamentais. Impedi-la é ato de discriminação que remete à intolerância de épocas passadas. Nesse sentido, a intenção de proteger as minorias é sempre louvável, ainda que, algumas vezes, a ênfase não seja na asserção e proteção da respectiva cultura em contexto diverso. Alguns militantes utilizam a ideia para simples fins de promoção pessoal e da ONG respectiva. $\mathrm{Ou}$ para respaldar um separatismo que vai contra a integridade territorial do Estado onde as minorias se encontram. Neste segundo caso, os defensores vão contra um dos princípios básicos da Carta das Nações Unidas recordados no artigo $8^{\circ}$, parágrafo $4^{\circ}$, da própria "Declaração dos Direitos das Minorias", de 1992 (meu erro no título aqui é proposital). A objeção a quaisquer propostas nessa área, uma vez apresen- 
tadas em plenário por membro do Comitê, é tarefa penosa para os demais. Além de desagradar ao autor e ao seu "eleitorado da sociedade civil", pode causar a impressão de que oposição é feita contra os integrantes das supostas minorias, ou pessoalmente ao colega.

Rita Izsák chamou a atenção, ainda, de maneira correta e oportuna, para o fato de que muitas "comunidades minoritárias são desprovidas de cidadania, situação que as deixa extremamente vulneráveis nas respectivas sociedades"18. Aplicável particularmente a grupos considerados roma, ciganos ou simplesmente nômades existentes há séculos na Europa, assim como a certas comunidades que se recusam a aprender o idioma majoritário oficial, o problema tende agora a estender-se a grupos crescentes de imigrantes, refugiados e demandantes de asilo.

\section{A ideia de normas complementares e a "islamofobia"}

44 No debate que se seguiu às exposições do painel da manhã, a maioria das delegações presentes elogiou a Convenção tal como existe, declarando ser necessário que os Estados-partes cumpram as recomendações do Comitê. Poucas, como as da Índia (cujo sistema de castas é condenado pelo CERD, sendo os dalit, ou párias, considerados vítimas de discriminação por descendência) e do Paquistão, em nome da Organização da Conferência Islâmica (interessada em banir ofensas à religião), e da Jamaica, pelos Estados caribenhos (em defesa da proposta de reparações pelas metrópoles coloniais), insistiram na necessidade de normas complementares acordes com a realidade contemporânea.

A ideia de normas complementares à Convenção de 1965, com o objetivo de atualizar as disposições existentes,

\footnotetext{
${ }^{18}$ Em inglês, "deprived of citizenship". Não sei se, ao mencionar esse fato, a relatora tinha também em mente as propostas discutidas na Europa de retirada de cidadania das pessoas acusadas de terrorismo.
} 
conquanto abordada muito superficialmente em Durban, por ocasião da Conferência Mundial de 2001, acha-se refletida no parágrafo 199 do Programa de Ação. Deu ensejo, assim, à criação, em 2002, de um grupo de trabalho intergovernamental para estudar o assunto, substituído em 2007 por um novo comitê de peritos, que se reúne até hoje para sugerir formulações. Como tudo o que é tentado no sistema como experiência, uma vez constituído um mecanismo, a tendência é de mantê-lo e fortalecê-lo indefinidamente.

Desde as primeiras consultas sobre a matéria, em 2002, o CERD se declarou contrário à elaboração de novo instrumento a esse respeito, fosse ele um tratado separado ou protocolo adicional à Convenção. Entre os motivos apontados ressaltavam o longo tempo e as dificuldades que as negociações e ratificações exigiriam e que poderiam servir de escusa para a não observância das normas em vigor. Ao argumentar contra a ideia, os membros do Comitê costumavam recordar, como o fizera o professor Thornberry e outros oradores na comemoração do cinquentenário, que, com as Observações gerais, o próprio CERD tem coberto os aspectos da discriminação não previstos no texto da Convenção, emergentes ou não depois de 1965.

Conforme evidenciado nas alocuções supramencionadas, a ideia tem sido aproveitada por diferentes Estados, movimentos étnicos e grupos regionais para fazer avançar as respectivas prioridades. Cada qual terá sua lógica. A mais delicada para o CERD, até porque já foi objeto de iniciativa malograda, diz respeito ao eventual enquadramento de "blasfêmias" contra figuras sagradas de religiões como manifestação de racismo.

Como consequência da publicação, em 2005, dos então chamados "cartuns dinamarqueses" de Maomé (publicados em jornal de Copenhague e reproduzidos alhures), seguidos de surtos de violência popular contra cristãos em vários países, alguns peritos muçulmanos tentaram, em 2006, fazer 
passar projeto de observação geral condenando o episódio e recomendando aos Estados-partes a proibição de jocosidades congêneres como expressões de ódio racial. A tentativa no CERD, em 2006, não teve êxito, uma vez que, independentemente do possível caráter preconceituoso das caricaturas em questão, as "blasfêmias" divulgadas no Ocidente não são exclusivas contra religiões específicas. Advêm do Iluminismo, do século XVIII, contra o clero e a dominação da Igreja católica. Não caberia ao CERD, nem a outros órgãos de direitos humanos, generalizar uma interpretação que constituiria censura a formas de liberdade de expressão não necessariamente racistas. Além disso, mais difamatória do islã como religião legítima haviam sido as reações de vandalismo e agressões físicas, envolvendo até a morte de uma freira. Evidência desse fato ocorre hoje com os atentados terroristas do autoproclamado Estado Islâmico, em particular o assassinato de jornalistas do Charlie Hebdo, imputados, sem qualificações, ao islã. Para con46 trabalançar excessos da liberdade de expressão, todos os países democráticos preveem a possibilidade de ações judiciais. A tais ações têm recorrido, aliás, regularmente, as comunidades muçulmanas na Europa, há anos, inclusive contra os autores das caricaturas dinamarquesas e contra o hebdomadário Charlie Hebdo, perdendo e ganhando causas, com retratações e indenizações, de acordo com a lei.

Entre os fenômenos recentes que depõem contra qualquer fé ou tradição, o mais notável não são desenhos ou piadas contra personagens religiosas, que sempre existiram, com ou sem conotações raciais, mas o fanatismo belicoso contra cultos e religiões específicas. Após longo período de submersão em águas tranquilas, esse tipo de fanatismo vem reemergindo furiosamente e ganhando adeptos, no islã como em outros credos, evangélicos e carismáticos, que rotulam os alvos de "blasfemos" ou "satânicos". É isso que precisa ser combatido. Em vista, contudo, de atitudes as quais venho notando entre os colegas em assuntos afins, e 
da radicalização das ONGs atuantes no Comitê e Secretariado, é difícil assegurar que as posições prevalecentes em 2006 fossem hoje as mesmas. Até porque, no Ocidente, precisa realmente ser combatida a renitente "islamofobia" - neologismo militante de que também abusam lideranças autoritárias de países muçulmanos -, compensada por uma espécie de "cristianofobia" mais contestatária do que alheia, cultivada no discurso ocidental "politicamente correto".

Curiosa e expressivamente, no painel da manhã do seminário, pelo que me lembro e se lê no "registro sumário" do Escritório das Nações Unidas em Genebra, não foram membros do CERD, nem Estados ou relatores temáticos, mas sim integrantes de movimentos da sociedade civil que chamaram a atenção para os acontecimentos mais marcantes do recrudescimento recente do racismo: as manifestações populares na Europa contra solicitantes de asilo; a reincidência de mortes com conotação racial por forças policiais nos Estados Unidos; o reforço da propaganda de ódio racial pela internet e outros meios de comunicação. Apenas "um orador" não identificado na página do Alto Comissariado para os Direitos Humanos é citado na página do Alto Comissariado referindo-se indiretamente ao terrorismo e seu relacionamento com o tema do seminário. Ao recordar que os "ataques chocantes no Líbano, França, Mali, Tunísia e outros países mostraram que o papel da Convenção permanece hoje tão relevante quanto há cinquenta anos", esse participante vocalmente consciente, mas anônimo nos registros consultáveis, opinou que "o combate ao racismo e à intolerância é uma das melhores formas de lutar contra ideologias extremistas"19. De minha parte, não creio que o combate apenas metafórico contra o extremismo manifestado em terrorismo, como o do

\footnotetext{
${ }^{19}$ Ver <www.unog.ch/unog/website/news_media.nsf/(httpNewsByYear_en) /68 0E41C32D3A84C0C1257F09005E04B0?OpenDocument $>$. Eu próprio não havia notado de imediato tal referência, cujos países mencionados foram todos objeto de ações reivindicadas pelo Estado Islâmico (ISIS ou DAESH).
} 
ISIS, seja hoje suficiente para enfrentar o problema em sua magnitude. Mas a lembrança foi oportuna, e o CERD deveria unir-se a essa voz solitária.

\section{Segundo Painel: Desafios atuais e caminhos para prosseguir}

Embora o título do painel da tarde fosse voltado para o futuro, algumas das principais exposições complementaram o quadro evolutivo do trabalho do CERD, focalizando categorias populacionais genéricas, como os afrodescendentes e os indígenas, além de minorias específicas, como os roma, ou grupos vulneráveis como os dalit do hinduísmo ou os integrantes de castas profissionais persistentes em muitos países. Cada orador privilegiou a importância da Convenção para os segmentos populacionais objeto da respectiva militância. É expressiva nesse sentido a simples enunciação da lista de oradores não governamentais inscritos: Rede Internacional de

48 Solidariedade com os Dalit, Associação de Advogados Coreanos Zainichi, Rencontre Africaine pour la Défense des Droits de l'Homme, Black Mental Health UK etc. Vários Estados também intervieram, acentuando suas prioridades ${ }^{20}$.

\section{Os temas permanentes dos afrodescendentes, dos indígenas e dos não cidadãos}

Enquanto as questões de minorias culturais ou religiosas e as práticas contemporâneas correlatas ao racismo, inclusive contra imigrantes, constituem temas novos na agenda internacional de direitos humanos, as discriminações contra negros e mestiços, indígenas e não cidadãos estão na pauta convencional do CERD desde o início. São, portanto, ou deveriam ser, temas permanentes.

\footnotetext{
${ }^{20}$ O Brasil falara na sessão da manhã, anunciando a realização, nos dias 3 e 4 de dezembro de 2015, em Brasília, da Conferência Regional da América Latina e do Caribe da Década Internacional dos Afrodescendentes (2015-2024), aprovada pela Resolução 68/237 da Assembleia Geral, em 23/12/2013.
} 


\section{Pessoas de ascendência africana}

A primeira exposição do segundo painel da comemoração foi dedicada ao tema permanente dos afrodescendentes. Estes, sob outras denominações, haviam sido os principais destinatários da Convenção de 1965, em particular quando facilmente identificáveis. Não obstante, com o passar do tempo e as mudanças no discurso, as prioridades se confundiram entre as ONGs, os Estados-partes e os membros do CERD. Recordo-me, a propósito, das palavras da perita sul-africana Nosipho January-Bardill, irritada com a obsessão "etnicista”, admoestando os colegas, em sessão recente: "Quando sou discriminada na Europa e outros continentes, é porque sou preta, não porque sou xhosa!”.

A luta contra a situação de inferioridade segregada dos negros nos Estados Unidos, associada ao desdobramento anti-apartheid da campanha internacional anticolonialista, foi, conforme já visto, a inspiração imediata da Convenção de 1965. O foco de atenções do CERD, no início de seu funcionamento, nos anos 1970 e 80, era, portanto, nas discriminações com base em raça ou cor. Somente mais tarde, a preocupação com "etnicidades" se firmou, superando as atenções com o racismo de inspiração visual. Diferentemente do que se poderia supor, as discriminações por descendência previstas no artigo $1^{\circ}$ da Convenção nunca se referiram, nem se referem hoje, a atos e omissões contra mestiços, ou filhos de estrangeiros, ou ainda de antigos membros da nobreza ou aristocratas depostos. Colocada na definição pela Índia, cuja Constituição havia abolido legalmente as castas, a descendência se referia à estratificação do hinduísmo, e hoje se estende, por analogia, às castas profissionais, remanescentes em algumas partes da África e da Ásia.

A expressão "afrodescendente" é neologismo oriundo da Conferência de Durban de 2001. Surgiu para acomodar posições do movimento negro norte-americano e caribenho, reivindicadas também por lideranças de outras latitudes, de 
incluir numa mesma categoria os mestiços (mulatos) e os negros, de pele escura. Partindo do pressuposto de que todos seriam vítimas das mesmas discriminações, o novo termo, que eleva uma genealogia escolhida acima de considerações epidérmicas, era indicador de uma "cultura africana”, imaginada como fator de união dos que com ela se identificam, e de diferença assumida perante os demais. Nesse sentido positivo, com suas razões respeitáveis, o neologismo se afirmou na área internacional em substituição a "negros" e "mestiços". Gera, porém, problemas desconsiderados em Durban, onde a maioria das ONGs que acorreu à Conferência procedia das Américas. Ao refletir situação dicotômica típica dos Estados Unidos e outras ex-colônias britânicas, a expressão provoca confusões em toda a América Latina, com suas características, preconceitos e discriminações diferentes, não sendo raros os casos de ininteligibilidade em recomendações do Comitê. Sem falar nos países da África, onde a expressão 50 é rejeitada por carecer de sentido.

A acomodação do pleito "africanista" americano não surpreende. Os Estados Unidos sempre tiveram papel de relevo na difusão da ideia dos direitos humanos. É normal que as postulações dos negros norte-americanos tenham sido defendidas e incorporadas como regras na Convenção de 1965. Surpreendente é o fato de militantes de outras latitudes terem passado a adotar as práticas dos Estados Unidos como modelo. Afinal, o racismo norte-americano, segregador e "purista”, era visto como uma aberração comparável ao sistema vigente na África do Sul. Por mais que já se denunciasse o racismo disfarçado em outras sociedades, o "racialismo" dos Estados Unidos, ao dividir recursos estatais por categorias raciais ou étnicas, era antítese evidente da igualdade prevista nas ideologias democráticas. Ao perenizar separações por categorias, assemelhava-se à teoria do apartheid como promotor do "desenvolvimento separado". Com uma diferença basilar: nos Estados Unidos, a categoria 
sul-africana dos coloured mestiços nunca chegara a existir. Desde o período colonial, os frutos de relações sexuais inter-raciais não eram considerados mestiços, porque também semibrancos, postulantes potenciais à cidadania livre. Eram imediata e totalmente "negros" para os senhores de escravos, a fim de aumentar o plantel. Foi pelo sentimento de revolta com as humilhações numa sociedade que permaneceu arraigadamente dicotômica muito após a abolição do escravismo que os membros do movimento norte-americano transformaram vício em virtude. Reunidos pelos brancos numa "raça negra" ampliada pela "gota de sangue impuro", cidadãos escuros e claros, igualmente discriminados, passaram a postular unidade entre si, com base numa ancestralidade comum não branca, adotando a ideologia do pan-africanismo como irmandade ou "nacionalismo africano" de todos os negros do mundo.

O CERD, que, em teoria, procura entender as diversas realidades dos Estados-partes por leituras dos relatórios, comunicações de ONGs e outras fontes de informação secundárias, não tem posições nítidas para as categorias étnicas em que devem ser divididas as estatísticas cobradas. Essencial é que a classificação se baseie na autoidentificação das pessoas. Não pode exigir dicotomias porque o planeta é plurirracial e historicamente mesclado. Embora nas recomendações fale sempre de "afrodescendentes" e o termo "mestiço" (ou equivalente, como "pardo") não apareça, nas orientações sobre a preparação de relatórios, o Comitê registra a importância de dados estatísticos sobre as "características étnicas" da população, "inclusive daqueles que resultam de uma mistura de culturas" $[\text { sic }]^{21}$. Não pode, assim, reprovar o uso da palavra "mestiço" ou equivalente nas informações recebidas, conquanto na arguição oral

21 Reporting guidelines, adotadas em agosto de 2007 (doc. CERD/C/2007/1, 13/6/2008, parágrafo 10). 
ponha em dúvida, com frequência, a autenticidade dessa identidade mesclada.

A primeira oradora do seminário em Genebra à tarde foi Mireille Fanon-Mendès-France, cidadã francesa de tez clara, presidente do Grupo de Peritos das Nações Unidas sobre as Pessoas de Ascendência Africana. Estabelecido em 2001 pela antiga Comissão dos Direitos Humanos em seguimento ao Programa de Ação da Conferência de Durban, de 2001, seu foco é temático, ainda que não planetário: a situação dos afrodescendentes na diáspora, com atenções voltadas para o continente americano.

Em sua exposição, a oradora ressaltou, sem indicação geográfica nominal, o acirramento do discurso político de extrema direita, juntamente com crimes de motivação racial contra afrodescendentes, cujas características, segundo ela, "pareciam inimagináveis" no mundo atual. A referência era à sequência de incidentes policiais nos Estados Unidos, 52 envolvendo mortes de negros, iniciada pela execução do jovem Michael Brown por policial branco em Ferguson, Missouri, em 2014. Mireille Mendès-France aludiu, também nesse contexto, aos instrumentos internacionais existentes, de combate à discriminação racial, com destaque para a Recomendação Geral n ${ }^{\circ} 34$ do CERD, assinalando que suas disposições precisam ser observadas, inclusive com adoção de legislação interna.

A Recomendação Geral n ${ }^{\circ}$ 34, adotada pelo Comitê após seminário realizado em 2011, no contexto do Ano Internacional dos Afrodescendentes, é de per si um novo e pormenorizado programa de ação a ser cumprido pelos Estados-partes da Convenção, adicional àqueles adotados em Durban, em 2001, pela Conferência das Nações Unidas e pela Conferência de Revisão de Durban, em Genebra, em 2008. De formato e conteúdo surpreendentes para documento oriundo de órgão de tratado, a Recomendação tem 66 parágrafos definidores e operativos, envolvendo medidas 
que vão desde ações afirmativas para os negros em geral à proteção especial para mulheres e crianças afrodescendentes; do combate ao discurso do ódio racial à administração equânime de justiça; de garantias aos direitos civis e políticos à promoção dos direitos econômicos e sociais dos afrodescendentes, passando pela revisão de livros escolares para erradicação de estereótipos e pelo ensino de história da África. Seu vasto escopo e sua pormenorização de atividades são compreensíveis pelo afã dos peritos redatores em demonstrar empenho para acomodar o maior número possível de pleitos de ONGs e de movimentos sociais. Os excessos tendem, contudo, a torná-la irrealizável pela maioria dos Estados. Alguns, contraproducentes, estimulam distorções, cobranças e preocupações com assuntos irrelevantes. Exemplos de atitudes desse tipo haviam sido vistas - e consagradas! - pelo CERD três meses antes, em agosto, por ocasião do exame de relatórios periódicos dos Países Baixos e da Costa Rica.

Os Países Baixos constituem um dos Estados-partes mais cuidadosos em matéria de "correção política" oficial, na linguagem e em outros campos semióticos. Não obstante, sua velha tradição natalina do desfile de um São Nicolau, velho branco gorducho como nosso Papai Noel, a cavalo, acompanhado de um jovem com o rosto escurecido a carvão, a pé, foi condenada como racista, passível de interpretação como elogio à escravidão. Conquanto o perito belga, Juiz Marc Bossuyt, indignado, explicasse que a tradição secular, compartilhada por seu próprio país, nada tem a ver com raça ou sistema escravista, sendo o rosto do Black Pete coberto de fuligem porque é ele quem passa pela chaminé para dar presentes às crianças, mais valeram as críticas de ONGs, a maioria das quais de fora dos Países Baixos. Algumas eram respaldadas por material da internet e impresso para distribuição aos peritos na forma de panfletos chocantes. Nesse caso artificial, que somente pode servir de galhofa para o 
cidadão comum e instrumento útil para racistas - o deputado neerlandês Geert Wilders, radical de direita eleito para o Parlamento Europeu, que sempre se aproveita dessas tolices, não é político isolado na atualidade -, mais do que a atitude do CERD, o que espanta é ver o quanto as sensibilidades se acham magnificadas. E afiadas! Daí à violência, resistente ou repressora - já verificada nos Países Baixos em manifestações a propósito dessa tradição popular -, para não falar de fenômenos mais graves, a distância pode ser muito curta.

Outro caso ilustrativo, na mesma sessão do CERD, envolveu o livro infantil Cocori, da Costa Rica. Premiado, traduzido e publicado em muitos países, entre os quais o Brasil, o pequeno clássico costarriquenho, de autoria de Joaquín Gutiérrez, lançado em 1947, conta história singela de um menino negro, Cocori, que vive com a mãe em região de floresta na costa caribenha. Travesso e curioso, o personagem entra num navio sueco de passagem e encontra pela primeira vez 54 uma menina loura de idade equivalente à dele. Ambos se espantam com o inusitado das respectivas figuras, mas logo se apaixonam. O navio vai embora com a menina, que deixa uma rosa com Cocori. A flor morre em pouco tempo, e o menino, na companhia de um mico, Titi, e uma tartaruga, Dona Modorra, sai pela floresta à procura de alguma explicação ou remédio que faça a rosa reviver. Nada consegue, mas, quando volta a casa, as sementes da rosa haviam florescido. E Cocori passa a ter uma roseira. É difícil conceber de que maneira qualquer pessoa possa sentir-se ofendida pela narrativa. Entretanto, segundo explicado na sessão, o caso já havia sido até levado à Justiça da Costa Rica por lideranças afro-costarriquenhas que queriam a retirada do livro do currículo escolar infantil. O resultado foi rejeição do pleito pelos juízes e, o que é grave, uma série de agressões verbais, aí sim de conteúdo racista, às autoras da ação judicial. No Comitê, chegou-se a ler a carta de uma menina negra que declarava chorar de vergonha com a ideia que o livro transmitiria 
dos afrodescendentes. Por quê? Por se tratar de um menino escuro na selva, provavelmente de comunidade cimarron ou quilombola, que, pelo fundamentalismo pan-africanista, não deveria estranhar nem namorar uma sueca? Malgrado oposições isoladas, inclusive porque nenhum dos membros havia lido o livro ${ }^{22}$, o CERD, como previsível, endossou as críticas e recomendou ao Estado-parte a retirada de Cocori das listas escolares. Quase recomendou também a formação de uma comissão para examinar todos os livros adotados em escolas, a fim de identificar conteúdos e estereótipos possivelmente ofensivos. Ou, seja, uma comissão de censura!

Apresentadas com revolta pela militância, cuja respectiva categoria foi e ainda é vítima de preconceitos discriminatórios, e acolhidas com hipocrisia pelo bom mocismo dominante, as interpretações que tudo encaram como "discurso do ódio" se prestam a finalidades antagônicas igualmente nocivas: de um lado, um purismo parcial imposto como camisa de força; de outro, uma imagem de futilidade, objeto de chacotas ${ }^{23}$. Infelizmente, é sob esse ângulo, de cobranças tolas, descabidas, que os direitos humanos passaram a ser vistos regularmente pelo cidadão comum. $\mathrm{O}$ excesso maximalista, mais irrealista do que a autocontenção do século passado, tem sido, aliás, uma característica das criações recentes na área dos direitos humanos. Como se o essencial da Declaração Universal já estivesse cumprido.

Longe de mim dizer que o discurso de ódio deva ser tolerado. Além de proibido pela Convenção, sua aceitação passiva,

\footnotetext{
${ }^{22}$ Eu próprio havia encontrado apenas um sumário na internet. Consegui o livro a posteriori e é dele que extraí o resumo aqui exposto. Como depois confirmei que nem sequer o relator, proponente da recomendação, havia lido o texto. Daí suas referências em plenário a expressões e ocorrência inexistentes, como a de que a menina teria confundido o menino com um macaco...

${ }^{23}$ Um ano depois da condenação do Black Pete (Zwarte Piet em holandês) pelo CERD, uma revista flamenga divulgava na capa e em reportagem de seis páginas nova moda para homens e mulheres em festas natalinas: roupas multicoloridas e rostos sorridentes enegrecidos com carvão (De Morgen, 19/11/2016, pp. 18-24).
} 
ainda que em nome da liberdade de expressão ${ }^{24}$, tende a banalizar o racismo. Tampouco creio necessário fazer comparações dos casos de Cocori ou da tradição do Black Pete com episódios congêneres também forçados no Brasil. Os exemplos se multiplicam em lugares diversos, acomodados ou não pelos governos. Com o mesmo tipo de interpretação ideológica e atitudes exageradas, sintomáticas do grau de hipersensibilidade cultural adquirida, o racismo e a discriminação racial não cessam, nem diminuem. Não é a simples facilidade de comunicação que explica a atual divulgação no Brasil de ofensas racistas pelas redes sociais com um nível de agressividade antes inaudito entre nós. Os dois lados se estimulam numa reciprocidade temerária.

Independentemente dos exageros, reconheço a importância de que se revestem as iniciativas variadas da ONU em favor dos afrodescendentes. São eles, ainda, as vítimas mais frequentes de discriminações em todo o mundo, certamente por56 que, quando escuros, são mais visíveis. Digo isso de maneira politicamente incorreta, pois o CERD e a hipocrisia reinantes repreendem os Estados-partes da Convenção quando se referem a "minorias visíveis". Em função desses pruridos excessivos, conforme já apontei em plenário, os negros, apesar de terem sido destinatários originais da Convenção quando elaborada, ficam hoje submergidos pela aluvião de perguntas e recomendações do Comitê a respeito de "minorias étnicas", conceito que, a rigor, quantitativa e etnologicamente os exclui.

\section{Os povos indígenas}

Impossibilitada de comparecer pessoalmente à comemoração em Genebra, a Relatora Especial do Conselho de Direitos Humanos para os Direitos dos Povos Indígenas ${ }^{25}$, Victoria

\footnotetext{
${ }^{24}$ É esse o argumento das reservas de muitos países ocidentais ao artigo $4^{\circ}$, alguns deles afirmam que a proibição tende a atrair visões preconceituosas contra os discriminados. ${ }_{25}$ Relatoria estabelecida em 2001 pela antiga Comissão dos Direitos Humanos (Resolução 2001/57), confirmada e renovada pelo Conselho até hoje.
} 
Tauli-Corpuz, filipina, enviou mensagem por vídeo, em que louvou o trabalho do CERD sobre seu tema. Salientou a Recomendação Geral n ${ }^{\circ}$ 23, de 1997, relativa aos direitos culturais dos indígenas, trazendo o foco das atenções para os direitos coletivos desses povos à posse e ao desenvolvimento de suas terras, mencionados no respectivo parágrafo $5^{\circ}$. Nesse sentido, seria para ela particularmente relevante o Procedimento de Alerta e Ação Urgente, que viria conseguindo reações positivas de Estados e organizações. Exemplo disso seria o controle que o governo das Filipinas havia passado a exercer sobre a mineração em certas áreas do país.

Conforme indiquei a propósito do discurso inaugural do presidente do Comitê, desde os anos 1960 e 70, o movimento dos indígenas, iniciado nos Estados Unidos e logo expandido para o sul do hemisfério, já assumia a identidade cultural própria dos "nativos" como diferença a ser preservada, com postulação de direitos coletivos. Essa afirmação diferencial comunitária foi ainda mais problemática do que o reconhecimento de minorias no direito internacional. Ademais outros motivos, os indígenas se afirmavam como povos originais do território de Estados soberanos, logo, em princípio, titulares naturais do direito à autodeterminação. Embora documentos da própria ONU qualificassem a autodeterminação pela independência política como atributo exclusivo de povos submetidos ao sistema colonial por metrópoles de fora, governos e juristas em geral resistiam à aceitação de povos distintos dentro do Estado nacional. "Povo" era sinônimo de "nação", constitucional e essencialmente una como identidade política ${ }^{26}$. O máximo que se poderia contemplar era a manutenção da cultura diferente, com suas formas de propriedade e

\footnotetext{
${ }^{26}$ Até mesmo a Constituição dos Estados Unidos, federação relativamente frouxa, foi elaborada com referência a "nós, o povo" como identidade única (We the people of the United States of America). Pela ótica do multiculturalismo, deveria ser "nós, os povos" (we the peoples).
} 
organização específica, dentro dos limites de reservas territoriais reconhecidas pelo Estado.

As resistências à expressão "povos indígenas", dotados de direitos coletivos, somente foram, em princípio, (quase) superadas nas Nações Unidas pela adoção - não consensual - pela Assembleia Geral, em 2007, da Declaração dos Direitos dos Povos Indígenas, sem força de tratado, depois de décadas de negociação em vários foros. Seu primeiro anteprojeto advinha, por sinal, de um grupo de trabalho da hoje extinta Subcomissão, cujos membros, presididos por jurista grega, eram todos procedentes de países sem população indígena (da América Latina, participou somente o perito cubano).

A Recomendação Geral n ${ }^{\circ} 23$ sobre "os direitos dos povos indígenas", citada pela Relatora Especial, havia sido adotada pelo CERD em 1997, dez anos antes da Declaração correspondente. Adiantava-se ao texto hoje oficial na ONU muito além do esperado de um órgão de tratado. Fazia-o sem hesitação 58 e sem fonte legal autorizada. Qualificando as comunidades indígenas como "povos", a Recomendação cobrava respeito ao direito coletivo desses povos "de possuir, desenvolver, controlar e usar suas terras comunais, territórios e recursos”, devendo eles ser ouvidos em todas as iniciativas, especialmente econômicas, que as envolvessem (parágrafo $5^{\circ}$ ).

A par da Declaração de 2007 das Nações Unidas e da Recomendação Geral de 1997 como bases referenciais, o CERD utiliza e insta aos Estados-partes aderirem à Convenção 169 da Organização Internacional do Trabalho (OIT). Adotada em 1989, essa inusitada "Convenção sobre os Direitos dos Povos Indígenas e Tribais em Países Independentes", seu título completo, extrapola a área de competência convencional da OIT. Corresponde, pelo conteúdo e pela forma, a uma abrangente carta de direitos especiais para uma categoria particular de pessoas. Seja pela adesão reduzida, seja por se tratar de instrumento oriundo de organização especializada em assuntos outros, não do órgão com compe- 
tência primária na matéria nas Nações Unidas - o Conselho de Direitos Humanos -, a Convenção 169 da OIT não costuma ser citada entre os instrumentos principais de direitos humanos. O que não significa, faço questão de ressaltar, que deva ser desconsiderada como referência importante para a defesa dos direitos específicos, individuais e coletivos, dos indígenas, onde se encontrem suas comunidades. Especialmente num país como o Brasil, onde os direitos específicos dos indígenas são consagrados na Constituição de 1988.

Ao examinar relatórios dos Estados-partes pertinentes, o CERD dá atenção especial à situação dos diferentes povos indígenas das Américas, dos sami da Escandinávia, dos povos considerados autóctones de outras regiões. Para os batwa de Ruanda e Burundi, os san da África Austral (Khoi-San na África do Sul), os chamados "pigmeus" da África Central e muitos outros grupos não integrados em diversos continentes, o Comitê cobra atenção e ações, recomendando seu reconhecimento oficial como "povo indígena”. Tal reconhecimento, que aparentemente realçaria a assunção da identidade diferente desses grupos, alguns dos quais são, aliás, transfronteiriços, deveria torná-los também titulares dos direitos individuais e coletivos proclamados pela Declaração de 2007.

Quanto ao Procedimento de Alerta e Ação Urgente, estabelecido no CERD nos anos 1990, em atendimento a pedido do Secretário Geral Boutros-Ghali para situações que pudessem conduzir a casos de genocídios como o de Ruanda, ele se foi estendendo aos poucos para acomodar queixas diversas recebidas de minorias variadas. A tendência culminou numa quase exclusividade de atenções para questões indígenas em diferentes países, de vários continentes, sendo as queixas predominantemente motivadas por iniciativas econômicas, estatais ou privadas, que abrangem terras ancestrais e exploração de recursos naturais nelas situados. É, portanto, justificada a observação da Relatora Especial que encara tal procedimento como um exercício complementar à sua função. 
Ao contrário de órgãos intergovernamentais políticos, ou comissões e cortes judiciais regionais, o CERD, no procedimento de urgência, é sempre cauteloso, pedindo e reiterando pedidos de informação aos governos, obtendo, certamente por isso, resultados construtivos de muitos. Os países não se limitam aos das Américas, porque a palavra "indígena”, traduzida em francês por autochtone, passou a significar "autóctone" também nas outras línguas, propiciando expectativas impensadas para minorias originárias em outros continentes. Os Estados geralmente respondem às indagações, apontando correções ou adotando medidas para resolver a questão.

A par desse trabalho, hoje quase rotineiro, voltado para terras indígenas, o Procedimento de Alerta e Ação Urgente, não convencional, está retomando seus objetivos originais. Foi nele que o Comitê lançou, por exemplo, em agosto de 2014, um primeiro alerta na ONU para a atuação genocida do autodenominado Estado Islâmico contra populações 60 pacíficas da Mesopotâmia, especialmente os yazidis.

\section{Os não cidadãos e os refugiados}

Uma terceira alocução sobre grupos populacionais em situação específica, que merece destaque pela oportunidade, foi a do Alto Comissário Assistente para a Proteção de Refugiados, Volker Turk, do ACNUR (Alto Comissariado das Nações Unidas para os Refugiados). Assinalando que, com um total de 60 milhões, nunca se havia confrontado número tão grande de refugiados, pessoas deslocadas e apátridas desde o fim da Segunda Guerra Mundial, o expositor ressaltou que as causas de seu sofrimento falam diretamente à Convenção. O desafio não se limita a combater as causas, que perduram. Requer também proteção para os demandantes de asilo, cujo espaço de refúgio vem encolhendo, ao passo que quinze conflitos começaram ou recomeçaram nos últimos cinco anos - ou seja, 15 entre 2011 e 2015! Em adição aos 10 milhões de apátridas existentes, a maioria 
integrante de populações minoritárias, pelos menos vinte países mantêm ou pretendem adotar leis de nacionalidade que permitam a retirada de cidadania com base em etnia ou religião. O Comitê deveria prestar atenção particular ao drama dos migrantes, refugiados, pessoas internamente deslocadas e apátridas.

Os refugiados, diferentemente das "minorias", não conformam um tema especial do Conselho dos Direitos Huma$\operatorname{nos}^{27}$. Desde o fim da Segunda Guerra Mundial, constituem a matéria de que trata concretamente o Alto Comissariado das Nações Unidas para os Refugiados (ACNUR), uma das agências mais importantes da família das Nações Unidas, existente desde 1949. Entretanto, desde pelo menos 2005, quando adotou a Recomendação Geral n ${ }^{\circ} 30$, sobre a discriminação contra "não cidadãos", expressão usada no artigo $1^{\circ}$, parágrafo $2^{\circ}$, da Convenção, o Comitê faz inquirições e recomendações a respeito dessa categoria de pessoas desprovidas da cidadania do Estado-parte examinado. Adota um sentido amplo para a expressão "não cidadãos", que, para o Comitê, abrange imigrantes em geral, refugiados políticos, candidatos a asilo, além de migrantes indocumentados e apátridas. Todos eles são termos não mencionados na Convenção. Com base na Recomendação Geral, o CERD controla as expulsões e deportações praticadas por Estados-partes ao avaliar seus relatórios, assim como a legislação doméstica sobre nacionalidade e condições de naturalização. Funciona, portanto, como elemento adjutório à atuação do ACNUR. Essa agência especializada, por sua vez, com equipes atuantes in loco, representa importante fonte de informação de primeira mão para o exame dos relatórios.

Além desse tipo de atividade regular na matéria, o Comitê adotou, pelo menos uma vez, em abril de 2015, con-

\footnotetext{
${ }^{27}$ Existe um Representante Especial para o tema das pessoas internamente deslocadas, criado por resolução de 2004.
} 
forme lembrado até pelo Presidente Cali Tzay no debate final do seminário, uma decisão no Procedimento de Alerta e Ação Urgente para chamar a atenção da ONU para os novos fluxos migratórios, maciços e praticamente incontroláveis, com grande número de mortos no Mediterrâneo e em mares do Sudeste da Ásia. Essa decisão, contudo, como quase todas as que não tratam de reivindicações da sociedade civil organizada, nem se dirigem a um governo específico, mal se tornam conhecidas fora da sala de reuniões. Permanecem submersas entre outras decisões e recomendações com público certeiro: Estados, ativistas não governamentais e lideranças de minorias específicas.

Certamente o que o Alto Comissário Assistente para a Proteção de Refugiados, do ACNUR, queria dizer na comemoração, mas não ousou, era que o CERD, na qualidade de órgão supervisor da Convenção, precisaria ficar mais sintonizado nas principais tragédias da atualidade. Os sofri62 mentos das pessoas em êxodo, antes, durante e depois da fuga, são ainda mais agravados pelas coerções e barreiras no percurso e no local de destino. Retratados como hordas a ameaçar nações civilizadas, esses emigrantes econômicos e prófugos de conflitos que não são seus, sofrem discriminações acentuadas pelo discurso do medo, exacerbado pelos meios de comunicação. Para impedir sua passagem ou permanência, Estados democráticos não hesitam em adotar métodos que têm sido comparados a práticas nazistas, desde as cercas de passagem a muros de arame farpado nos locais de recepção; desde o isolamento em sítios assemelhados a campos de concentração ao confisco de pertences. A rejeição e a agressividade xenofóbica nos países de chegada exacerbam, por outro lado, sentimentos de humilhação, inclusive entre os já assentados. Ao fazer aumentar o ressentimento desses não cidadãos ou, como se diz, "cidadãos de segunda geração", elevam o potencial de criminalidade contra as mulheres, por exemplo, no réveillon de Colônia, 
Alemanha, de 2015 para 2016 - e de atração pelo islã primitivo como forma de rebeldia e autoafirmação. Multiplicam-se, assim, fatalmente, os voluntários potenciais para a "guerra santa" e os propagandistas do terror suicida como caminho para o paraíso.

\section{O procedimento convencional de comunicações individuais}

Em matéria de métodos e práticas do CERD, a intervenção mais detalhada da cerimônia foi do juiz Régis de Gouttes, magistrado da Cour de Cassation de Paris, que havia sido membro do Comitê durante 24 anos - seis mandatos sucessivos -, em que muito contribuiu com sua experiência de jurista e nele presidiu o Grupo de Trabalho sobre comunicações.

Inovação ambiciosa da Convenção, o procedimento de comunicações individuais é previsto no artigo 14, segundo o qual os Estados-partes podem reconhecer ao CERD competência para deliberar sobre casos esgotados na respectiva jurisdição, cujas vítimas se considerem insatisfeitas com a justiça doméstica. Extremamente ousada numa época em que o conceito de soberania era dogma, a novidade no âmbito internacional era tão significativa que requeria - e ainda requer - declaração expressa de aceitação dos respectivos Estados-partes ${ }^{28}$.

Por mais que o procedimento de comunicações inaugurado pela Convenção tenha representado uma abertura rumo à internacionalização da justiça na área dos direitos humanos, e em contraposição aos esforços de membros competentes na matéria como De Gouttes, hoje substituído pelo também juiz Marc Bossuyt, o que tem predominado, na prática, é seu abuso frequente. De parte dos remetentes,

${ }^{28}$ Conforme assinalado por De Gouttes, do total de 177 Estados que haviam ratificado a Convenção até novembro de 2015 , somente 57 haviam emitido a declaração de aceitação. 
porque levam ao Comitê casos descabidos, forçando o CERD a considerar inaceitável a maioria das comunicações. De parte dos membros do Comitê, ciosos de não parecerem coniventes com atos discriminatórios, pela facilidade com que fazem cobranças sem sentido aos Estados. A título de ilustração, recordo aqui um caso antigo que me fez distanciar-me da maioria das deliberações nesse procedimento. Em 2003, diante de uma comunicação de aborígene local que se considerava ofendido, o CERD já recomendou à Austrália que mudasse o nome de um setor de estádio de futebol, batizado de E. S. "Nigger" Brown Stand em homenagem a jogador falecido (nigger é palavra ofensiva para negros norte-americanos, mas o jogador australiano, dos anos 1960, era branco, e o apelido adotado vinha da graxa que usava nas chuteiras). Previsivelmente, o efeito alcançado foi apenas de irritação do governo australiano, de que o Comitê teve conhecimento depois.

64 Sem especialização profissional anterior como magistrados, os "peritos" oriundos de outros setores se mostram demasiado simpáticos com as vítimas e indignados com os alegados ofensores, diante de queixas que confundem ressentimento com violação de direitos. Confundem, assim, eles próprios, a ideia de justiça, inspiradora do procedimento previsto na Convenção, com empatia e paternalismo.

\section{A questão da "visibilidade"}

$\mathrm{Na}$ fase de comentários finais do painel da tarde, a mesma oradora que se referira ao ressurgimento de formas de racismo "inconcebíveis" na atualidade, Mireille Fanon-Mendès-France, presidente do Grupo de Trabalho sobre Pessoas de Ascendência Africana, expressou sua opinião, amplamente compartilhada, de que os afrodescendentes ainda sofrem, com frequência, de "invisibilidade". Tendo em conta a rejeição peremptória do CERD a qualquer referência a "minorias visíveis" pelo aspecto fenotípico, e levando 
em consideração o fato de que já quase nenhum Estado utiliza o argumento da miscigenação para ocultar preconceitos, talvez a menção nesse caso quisesse apenas assinalar a pequena participação de negros em órgãos diretivos econômicos e políticos, ou em programas de televisão.

Essa deficiência representativa, que vem sendo compensada aos poucos, inclusive em países da Europa e da América Latina, tende, de fato, a refletir preconceitos alimentadores de discriminações. Constitui uma das áreas em que podem caber diferentes "medidas especiais", públicas e privadas. Outra espécie de significado crítico possível envolve a não assunção da identidade "de origem" por pessoas e grupos ditos "assimilados". Seria o caso de "mestiços" que não se identificam como negros, ou grupos étnicos "aculturados", que não se assumem ou não se veem como "diferentes". Em qualquer desses dois casos, a questão da "visibilidade" não é redutível a maniqueísmos, exigindo ponderação da parte de quem acusa.

Dois tipos de motivação, pelo menos, podem ensejar preferência subjetiva pela "invisibilidade": medo de acirramento de ânimos e vontade real de assimilação na maioria. Ambos merecem respeito. O primeiro decorre de circunstâncias negativas, em que a sociedade dentro da qual o grupo respectivo se encontra pode tornar-se mais ameaçadora com base na identificação comunitária. É o caso dos países europeus que se recusam a fazer perguntas sobre etnia ou religião para não desenvolver mais preconceitos. O segundo caso tem causa "positiva": muitos imigrantes optam pela cultura de acolhida em escolha racional. A ex-parlamentar neerlandesa, originalmente somaliana, Ayaan Hirsi Ali, foragida da misoginia comunitária doméstica, e o comediante francês, originalmente camaronense, Gaston Kelman, cuja negritude não ideológica assume sem coerções, não são casos raros, embora sempre condenados pelos radicais do diferencialismo. Tampouco nosso Machado de Assis era "caiado", como 
alguns disseram com horror. Era biologicamente mulato, bem-sucedido em sociedade mestiça de cultura predominantemente europeia, num período em que vigiam ainda os restos do escravismo, e o racismo tinha laivos "científicos" de hierarquização natural. Em sua época, os sincretismos brasileiros, hoje repudiados pelos puristas da negritude, ainda não haviam sido estudados, nem eram sequer percebidos.

Por mais que o multiculturalismo contemporâneo ensine proteção às "etnias" supostamente "puras", não se pode denegar o direito, individual e coletivo, de optar por aquilo que se quer ser. É esse o sentido das liberdades fundamentais na Declaração Universal dos Direitos Humanos, especialmente as liberdades de consciência (artigo 18), de expressão (artigo 19) e de "participar livremente da vida cultural da comunidade" (artigo 27) - único direito cultural por ela consagrado. Inadvertida ou propositalmente atuante numa linha essencialista, o CERD, que dedica enor66 me atenção à situação dos roma - tal como a Relatora para Minorias e sua assessoria no Secretariado -, não consegue conceber que pessoas e clãs não ameaçados, especialmente a partir da segunda geração, não se identifiquem voluntariamente como roma ou outras "minorias nacionais ou étnicas". Até recentemente, no Brasil, era natural que os filhos de libaneses, alemães, russos, italianos, não se preocupassem com a língua dos pais, optando pelo português como língua materna. E que se considerassem simplesmente brasileiros, não árabes, russos, teuto-brasileiros, ítalo-brasileiros ou afrodescendentes. Tais fatos, para nós corriqueiros, sempre foram mal compreendidos fora.

Quase toda a complexidade da questão da visibilidade dos negros do Brasil atual parece-me contida em três lembranças de Ana Paula Lisboa (2016) em bela crônica sobre viagem a Angola. Nela, a militante brasileira recordava, entre suas saudades de Luanda, três momentos importantes para o assunto de que falo: (1) quando ouviu de seu amigo Iuri de que "a 
culpa da alienação de Angola é das novelas brasileiras, e que o preto brasileiro dá muita importância ao racismo"; (2) quando recordou que já explicara ao mesmo Iuri, em encontro no Brasil, sobre o racismo em que ele se atrapalhara: "quando se tem um presidente negro, quando as propagandas são todas com pessoas negras, quando as novelas são negras, os cantores são negros, é realmente difícil saber o que falar"; (3) quando, sentada na calçada do porto de Luanda, chorara ao ouvir de seu interlocutor Dario: "o problema de Angola é que as pessoas ainda passam fome, e a fome tira a dignidade das pessoas". É claro que se poderia argumentar longamente sobre a recordação número 2. Mas não é isso que interessa aqui.

A par de todas as falas e omissões já comentadas neste artigo, dois assuntos importantes deixaram de ser lembrados no seminário de Genebra, no dia 26 de novembro de 2015. O primeiro deveria interessar a todos: a pobreza em nível de miséria, da fome, que "tira a dignidade das pessoas", e não é mais encarada como problema sem cor nem gênero. O segundo, envolto em desinformação, diz respeito à questão das quotas raciais.

\section{A pobreza excluída da linguagem}

A discriminação econômica, social, cultural, política e civil contra os pobres, não prevista nem proibida por lei, é a forma de discriminação mais comum de todas. Mas ela não é tratada, nem referida no CERD.

Um pouco porque existe o Pacto sobre Direitos Econômicos, Sociais e Culturais (não confundir com "direitos das culturas”) de 1966, com órgão de tratado correspondente, um pouco porque a Convenção de 1965 lista tais direitos humanos com visão antidiscriminatória (artigo $5^{\circ}$, alínea e, de i a vi), o CERD somente trata de assuntos atinentes à pobreza pela ótica das "etnias". A abordagem é sempre particularizada, formulando indagações e recomendações sobre o trabalho, o emprego, a 
educação, a moradia, a saúde de minorias e grupos vulneráveis, dos roma, dos povos indígenas e dos afrodescendentes, com atenção também para as mulheres desses segmentos.

Sobre a pobreza como problema em si não se falou no aniversário da Convenção, como quase não se fala no CERD. O assunto é tabu em tempos de globalização e multiculturalismo. Ainda se afirma que "a pobreza tem cor" com mais convicção do que no passado, para contrabalançar o dito "dinheiro não tem cor". Mas o problema das condições de usufruto de direitos e liberdades que afeta a maior parte da humanidade não parece mais existir no discurso contemporâneo. Provavelmente porque recorda o conceito transcultural de classes sociais, repudiado ainda que sem referência à noção marxista de luta de classes. Conforme explicita Walter Benn Michaels (2006), em livro de título expressivo e subtítulo eloquente ${ }^{29}$, ao se examinar a questão das disparidades econômicas pelas óticas exclusivas do racis68 mo e do sexismo, a desigualdade passa a ser decorrência de preconceitos, não do sistema (apud Caldwell, 2006).

A rejeição pós-Guerra Fria à ideia de pobreza como problema independente de raça ou etnia é tamanha que o CERD, em agosto de 2015, ao recomendar aos Países Baixos que controlassem os efeitos daninhos de atividades de mineração por multinacionais neles registradas, alguns membros do Comitê queriam singularizar somente os indígenas como vítimas da degradação ambiental. Por mais que se assinalasse que todos os habitantes de áreas degradadas, geralmente pobres, são prejudicados pela exploração predatória, a insistência se mantinha. Foi preciso um perito negro latino-americano, o colombiano Pastor Murillo, observar que a maior parte das terras contaminadas nos Estados Unidos são habitadas por afrodescendentes para que os autores do projeto aceitassem modificação na

29 The trouble with diversity: how we learned to love identity and ignore inequality ("O problema com a diversidade: como aprendemos a amar a identidade e a ignorar a desigualdade"). 
proposta. O texto final passou a ser: "efeitos adversos no gozo dos direitos humanos, em particular de povos indígenas, grupos minoritários e comunidades locais, e ao meio ambiente". Sempre sem citar os pobres.

A primeira menção ostensiva à pobreza como fato social, nos últimos anos, curiosamente aceita - e, até, enunciada - pelo então perito norte-americano Carlos Vázquez, ocorreu na consideração do relatório periódico da Santa Sé, em novembro de 2015. Na qualidade de principal arguidor para o caso, o advogado em Washington incluiu entre os "aspectos positivos" do informe "a ênfase conferida pelo Papa Francisco à luta contra a pobreza [...], pois os pobres são frequentemente indivíduos pertencentes a grupos raciais ou étnicos marginalizados na sociedade" 30 .

A menção às vítimas pertencentes a minorias justificava-se pela exigência de "puristas" no Comitê, entre os quais o próprio relator, sem a qual a Convenção nada teria a ver com o assunto. Por outro lado, esses vigilantes do texto pretendiam condenar, na mesma ocasião, sem referência ao relatório da Santa Sé, a canonização pelo mesmo pontífice do frade franciscano espanhol Junípero Serra, fundador da primeira missão evangelizadora da Califórnia, no século XVII, criticada por indígenas da área. Somente a custo foi possível convencer os apresentadores da proposta de que o CERD nada tinha a ver com esse assunto. Conquanto se procure compreender os motivos históricos dos indígenas, segundo os quais o novo santo católico teria sido responsável por um "genocídio cultural", o respaldo pelo Comitê a protesto contra uma consagração cultual, com efeitos somente para os fiéis, soaria como se um grupo de pessoas, eleitas para outros fins, tivesse legitimidade para condenar missais, preces, ladainhas, quiçá a Bíblia, a Torá, o Corão, por seus trechos discriminatórios.

\footnotetext{
${ }^{30}$ Committee on the Elimination of Racial Discrimination, Concluding Observations on the combined sixteenth to twenty-third periodic reports of the Holy See (doc. CERD/C/ VAT/CO/12-23, parágrafo 4, alínea c, 11/1/2016).
} 
A leitura de fatos do passado com valores exclusivos do presente é comum e, talvez, compreensível. A disposição de membros de um órgão de tratado para aceitar interpretações desse tipo é absurda. Reflete a obsessão com posturas ditas "politicamente corretas". Herdeira distante e distorcida da semiologia dos anos 1960 e 70 e das interpretações epistêmicas de Foucault, a "correção política" atual nada tem de emancipatória. Contraparte paternalista do "vitimismo" das minorias, aceita burcas, punições corporais, censura prévia, cerceamento de liberdades e outras violações de direitos humanos desde que decorrentes de tradições não ocidentais. Não registra, porém, adequadamente, gestos de humildade já feitos. Como os do mesmo Papa Francisco, comprovadamente preocupado com os oprimidos de todo o mundo, ao pedir perdão pelos erros da Igreja, inclusive contra os índios na colonização da América ${ }^{31}$.

70 A questão das quotas

O CERD não tem, nem pode ter, posição definida sobre a utilização de quotas. Sua insistência é em favor de "medidas especiais" previstas na Convenção. Sua mais recente recomendação na matéria é de 2009, a Recomendação Geral $\mathrm{n}^{\circ}$ 32, intitulada "Sentido e Alcance das Medidas Especiais na Convenção sobre a Eliminação de todas as Formas de Discriminação Racial”. Nela, o aspecto mais relevante talvez seja a reafirmação, no parágrafo 5, de que a Convenção é um instrumento vivo a ser aplicado levando em conta as circunstâncias da época, assim como o contexto dos

\footnotetext{
${ }^{31}$ No mesmo parágrafo em que alguns peritos pretendiam condenar a canonização do frei Junípero Serra, condenação que consegui impedir, o CERD saúda o pedido de perdão do Papa Francisco durante viagem à Bolívia, para assinalar em seguida "as preocupações expressas por povos indígenas com o legado corrente e os efeitos da Doutrina de Descobrimento endossada na bula Inter Caetera (1493) e outras bulas papais correlatas" (Committee on the Elimination of Racial Discrimination, Concluding Observations on the combined sixteenth to twenty-third periodic reports of the Holy See (doc. CERD/C/VAT/CO/12-23, parágrafo 16, 11/1/2016).
} 
Estados-partes, sem prejuízo para a qualidade universal de suas normas $^{32}$. Supostamente inspirada em prática dos Estados Unidos, a opção pela reserva de vagas tem aspectos pouco notados, ou deliberadamente esquecidos. Começando pelo fato de que quotas raciais são banidas nos Estados Unidos.

É realmente difícil apurar o que predomina no emaranhado de leis, consultas, instâncias e decisões que compõem a jurisprudência daquele país na matéria. Tenho observado isso inclusive quando procuro esclarecimento definitivo junto a professores americanos do ramo. Pode-se afirmar, porém, que, em contraposição aos que propõem quotas como elemento essencial para fazer avançar a luta antirracista na América Latina, os Estados Unidos, por decisão da Suprema Corte, no julgamento do caso Regents of the University of California v. Allan Bakke, proíbem alocações quantitativas de vagas raciais em universidades desde 1978. E desde outubro de 2013, conforme decisão também da Suprema Corte, em outro caso abaixo referido, consideram inconstitucional a utilização de raça ou etnia como critério de ação afirmativa em qualquer nível escolar. Logo, se a América Latina atualmente adota quotas, o modelo de hoje é local, de nosso continente, não da América do Norte ${ }^{33 .}$

Vigentes em universidades durante, pelo menos, duas décadas, as quotas nos Estados Unidos foram úteis para a formação de uma classe média negra influente - e um segmento "latino" com personalidades afluentes. Vários empresários e parlamentares, afrodescendentes e hispânicos, foram delas

\footnotetext{
32 General Recommendation $n^{\circ} 32$ - The meaning and scope of special measures in the I.C.E.R.D., doc. CERD/CG/32, publicada em 24/9/2009.

${ }^{33}$ Encarada como "desenvolvimento positivo" pelo Grupo de Peritos sobre as Pessoas de Ascendência Africana, decisão da Suprema Corte dos Estados Unidos, em junho de 2016, no julgamento da ação Fischer v. University of Texas at Austin et al., voltou a aceitar "a inclusão da raça entre os elementos a serem levados em consideração no processo de matrícula" (Report of the Working Group of Experts on People of African Descent on its mission to the United States of America, doc. A/ HRC/33/61/Add.2, de 18/9/2016). Mas as quotas continuam a ser proibidas.
} 
beneficiários. Mas tanto quotas como outras medidas especiais não anulam preconceitos. Nem foram previstas, na Convenção, para esse fim. Podem até fortalecê-los, pois aumentam a concorrência. Ao proporcionarem condições de competitividade a pessoas de grupos marginalizados, podem gerar novas rejeições e mais exigências. O Presidente Barack Obama chegou a ser "denunciado" como não americano. Alguns acharam que, por não dar prioridade às raças, o mesmo presidente havia "traído" a causa negra. E no Brasil de hoje, onde as medidas de inserção já visibilizam a atuação de negros em áreas de que não participavam, registram-se manifestações de racismo e antirracismo mais ofensivas e radicais do que antes. Seria isso mais um sintoma de nossa americanização habitual?

Para evitar distorções no longo prazo, as medidas especiais previstas na Convenção necessitam ser temporárias. Assim, embora a Convenção não estivesse nas mentes

72 decisórias, não se pode dizer que houve violação de suas disposições pelas ações de estados norte-americanos que foram abolindo as quotas, ou pelos magistrados que as foram interpretando progressivamente como contrárias à Constituição. Tampouco deveriam causar constrangimento as afirmações recentes dos Estados Unidos e do Reino Unido, de que preferem atuar com diferentes formas de apoio às camadas pobres da população, pois elas ajudarão minorias e grupos vulneráveis. Por outro lado, conquanto engendre desapontamentos, não chega a causar surpresa, que o Grupo de Peritos da ONU sobre afrodescendentes tenha concluído, após avaliação recente, que os Estados Unidos se encontram "distantes da superação da discriminação racial sistêmica e institucionalizada em todos os níveis". ${ }^{34}$

\footnotetext{
34 "Human rights experts find racial discrimination in the USA alive and thriving" $(3 / 2 / 2016$, press release, <www.ohchr.org $>)$.
} 
Poucos países no mundo adotam quotas raciais. Os apoios a grupos vulneráveis se concentram no financiamento aos estudos, na abertura de escolas com professores habilitados nas línguas das minorias locais, na construção e oferta de moradias populares em áreas comunitárias, na facilitação de acesso ao emprego, à saúde, à cultura, a serviços públicos onde a incidência de discriminações seja mais provável. No continente africano, o único país que adota quotas raciais é a África do Sul, com vistas a corrigir efeitos prolongados do apartheid. Algumas ONGs já apresentam ao CERD queixas de que o sistema, proporcional aos números da cada região, ignora os integrantes de grupos minoritários, como o dos indianos, onde a presença coletiva respectiva é pequena. Os países ex-comunistas da Europa Centro-Oriental e balcânica são os que mais adotam quotas, para acomodar representantes de minorias nacionais no Parlamento. Estados com populações minúsculas, oriundos do velho Império Austro-Húngaro, ou da União Soviética desfeita, mantêm dezenas de separações classificatórias por origem nacional ou étnica (nesse segundo caso, geralmente judeus, valáquios e roma), com quotas de representação e partidos políticos exclusivos. Mais comuns em todos os continentes são as quotas para as mulheres.

Não pretendo insinuar que medidas de ação afirmativa devam ser repudiadas onde quer que seja. Muito antes de entrar para o CERD, eu próprio já havia trabalhado, no Brasil, em favor de iniciativas para a promoção dos negros. Acho importante, porém, nesse sentido, uma explicação pouco divulgada, dada pela delegação dos Estados Unidos na defesa de seu relatório periódico ao CERD, em agosto de 2014. Respondendo a indagação de perito, disse Catherine E. Lhamon, Secretária Assistente para Direitos Civis no Departamento de Educação, do Governo Obama: “A propósito da decisão da Suprema Corte no caso Schuette v. Coalition to Defend Affirmative Action, o Departamento de 
Educação tem publicado uma série de orientações para garantir a diversidade em todos os níveis do sistema educacional e alcançar o fim da segregação acadêmica. Embora quotas não sejam mais aplicadas, há outras maneiras de assegurar que as minorias estejam representadas na educação superior" 35 .

A última intervenção na comemoração de 26 de novembro não falou de quotas, mas é importante para conhecimento dos afrodescendentes na diáspora. Quem a fez foi a renomada ativista negra norte-americana Gay McDougall, ex-integrante do CERD e reeleita para novo mandato a partir de 2016. Ex-Relatora Especial para Minorias do Conselho de Direitos Humanos, que precedera a atual Rita Izsák, Gay McDougall havia sido convidada como expositora na qualidade de presidente do Conselho Diretor do Grupo Internacional dos Direitos das Minorias (Minority Rights Group International), rede de 150 orga74 nizações não governamentais atuantes na defesa de minorias étnicas em todo o mundo. Sua intervenção, elogiosa do CERD, Comitê que, em sua opinião, precisaria ser mais ouvido e fazer-se mais ouvir, foi relevante pelo eco que ela sempre obtém nas esferas das ONGs, dos órgãos de tratados, da academia. Nessa exposição, Gay McDougall, tal como Rita Izsák o fizera com sua experiência de mulher roma, recordou sua vivência pessoal de ativista afro-americana desde o tempo das "Leis Jim Crow", que mantiveram a segregação legal nos Estados do Sul, antes escravistas, até a década de 1960. Além de qualificar sem hesitações o sistema prolongado por tais leis de "versão norte-americana do apartheid" - comparação que o mundo evitava fazer para não ofender os Estados Unidos -, a expositora assinalou que, para graduar-se em estudos de nível superior, precisou recorrer a instituição acadêmica exclusivamente

${ }^{35}$ Summary record da sessão $n^{\circ}$ 2300, em 14/8/2014, parágrafo 20. 
negra, não integrada, observando, sem juízo de valor, que a instituição assim permanece até hoje.

$* * *$

Pelo que se pode ver dos comentários pincelados, as críticas que faço ao CERD se assemelham às críticas feitas no Brasil às posturas atuais do movimento negro. Resumidas em sua essência, elas giram em torno de um ponto comum: sua "americanização". Resta saber se é exatamente isso que ocorre no CERD. E se haveria alternativa nas circunstâncias presentes.

Tal como qualquer órgão das Nações Unidas, o CERD inexiste como entidade separada de seus integrantes. Nos órgãos de tratados, os membros não são Estados, são indivíduos, que tampouco existem no vazio. Na qualidade de "peritos", refletem, mais do que os delegados oficiais, as respectivas culturas. Estas, no mundo globalizado pelas tecnologias de comunicação, pela informação instantânea superficial e parcial, assim como pela massa de produtos de "entretenimento" oriundos dos Estados Unidos, são todas "americanizadas". Sem contar aldeias isoladas ou casos de regressão a modelos medievais totalizantes, todas as culturas urbanas atuais, guardando as hierarquias e repressões próprias, parecem querer ser, sem o dizer, “americanas". É isso que produz o discurso hegemônico nas Nações Unidas e alhures desde o fim da Guerra Fria, mais do que o exercício do poder político de Washington, ou o velho imperialismo econômico, que os terceiros disputam.

Não se pode corretamente dizer do CERD que seja "americanizado". Até porque, nos já quinze anos de minha participação como membro, dois dos três peritos norte-americanos de que fui colega até 2015 eram politicamente incorretos, contrários à "ação afirmativa", como o são muitos analistas e ativistas "negros" daquele país. O "purismo" multiculturalista pode ter sido expandido por teóricos da 
academia e militantes de minorias dos Estados Unidos. Mas suas origens são outras: os ingleses do Império Britânico que se recusavam a conviver com "nativos"; os racistas de todo o mundo que pretendiam esmagar as diferenças; os pensadores franceses exagerados na desconstrução da Modernidade; os canadenses que adotaram a primeira "Lei do Multiculturalismo" em 1988 para manter o Quebec unido; o obscurantismo em que têm decaído os relativistas ferrenhos e os defensores da pós-modernidade como superação das "grandes narrativas" - metarécits, no dizer de Jean-François Lyotard (1979, p. 7).

Uma das exigências convencionais para que um candidato a membro de órgão de tratado seja aceito reside em sua "imparcialidade", vista como independência diante do Estado que o indica. Prevista para evitar o uso dos comitês como instrumentos de governos, a interpretação dessa exigência persiste sem adaptações. Não leva em conta o temor dos elei76 tos de desagradar aos setores que os escolhem, a credulidade excessiva diante de qualquer queixa, a subserviência perante organizações e movimentos da sociedade civil. É mais comum ver peritos acusarem Estados poderosos do que fazerem questionamentos a ONGs que nitidamente exageram.

Desde os anos 1970, já se sabia que os órgãos das Nações Unidas compostos por "peritos" tendiam a privilegiar as posições não governamentais. Numa fase em que o Estado era uma instituição forte, e as ditaduras de esquerda e de direita abundavam, isso era necessário. As ONGs comprovavam-se imprescindíveis na área dos direitos humanos porque, movidas pela ética weberiana da convicção, constrangiam internacionalmente regimes violadores sem ética. Elas ainda são importantes. Algumas, admiráveis, salvam vidas, como as que agora ajudam diretamente migrantes e refugiados, ou orientam a juventude das favelas em caminhos para a cidadania. Delegados governamentais, por sua vez, dizia Celso Lafer em 1994, "não podem deixar de con- 
siderar a complexidade dos fatores políticos incidentes no assunto"36, de atuar, portanto, com a ética da responsabilidade. Num período perigoso como o de hoje, os membros de órgãos de tratados, supostamente eleitos com base em sua "elevada estatura moral e reconhecida imparcialidade" (artigo $8^{\circ}$ da Convenção), não podem ser como os cristãos convictos apenas de sua fé, no exemplo de Max Weber (apud Sartori, 2003, p. 166), agindo bem e deixando as consequências nas mãos de Deus. Todos os atores no campo social precisam equilibrar as duas éticas. Especialmente aqueles que compõem órgãos de tratados.

Evidentemente, os militantes de direitos de minorias não são criadores dos fundamentalismos. Como explicava, na virada do século, Zygmunt Baumann (2001, pp. 89-109), formulador do conceito de "modernidade líquida" para expressar a pós-modernidade em tempos de globalização econômica, o recurso à diferença como proteção das pessoas é provocado pelo cerceamento individual e coletivo em que os diferentes se encontram. Isso não impede que os excessos de cobranças em favor de minorias, de divisões em situações esgarçadas, de medidas fragmentadoras de "sociedades líquidas", sirvam mais às lideranças, dos dois lados das disputas, do que aos grupos diferentes que devem ser protegidos.

É possível afirmar sem erro que o CERD teve papel relevante ao longo dos cinquenta anos de existência da Convenção. Além de constituir um observatório supranacional permanente, o Comitê, com a legitimidade de que é investido, tem conseguido mudanças importantes nos Estados-partes. Elas não se limitam ao reconhecimento da pluralidade cultural da população e de ocorrências racistas contra a vontade do governo. A maior parte das modificações ocorre no âmbito legislativo. Muitos dos relatórios periódicos assinalam

${ }^{36}$ No Prefácio do meu livro Os direitos humanos como tema global (Lindgren-Alves, 2011, p. xxi). 
novos textos legais adotados a partir de recomendações do Comitê. As áreas são diversas, abrangendo a concessão de nacionalidade, a proibição de propaganda racista, o acesso à educação e a serviços públicos, quase toda a gama de direitos humanos listados no artigo $5^{\circ}$ da Convenção. O que falta é uma atitude corajosa contra excessos, que não cabe somente ao Comitê. Em conversas privadas comigo, quase todos os colegas reconhecem os exageros e erros dos modismos. Simplesmente os endossam para não parecerem "racistas".

O CERD é parte integrante do sistema internacional de proteção aos direitos humanos. Suas posturas, com erros e acertos, reproduzem e retroalimentam o discurso dominante em cada fase. Desde meados da década de 1990, tal discurso se modificou, confundindo o entendimento dos direitos humanos como direitos de todos, que sempre haviam sido. Em lugar do igualitarismo universalista de antes, considerado "de direita" porque individualista e "eurocêntrico", o cultura78 lismo particularista, que antes era "de direita" e hoje é proclamado "de esquerda", assumiu o proscênio. O CERD passou a privilegiar as etnias, com foco no direito à diferença. Ao fazê-lo, quase abandonou as discriminações raciais "antigas", com base em cor. Ao optar pelas etnias, seguindo as ONGs e a militância vocal de minorias, optou também, desnecessariamente, pela rejeição a miscigenações, como se fossem maléficas. As palavras "mestiçagem", "sincretismo", "hibridismo" são raras, quase interditas nos trabalhos.

A defesa das identidades é, em princípio, positiva. Sua lógica é, porém, a mesma daqueles que agem contra minorias. Além disso, as identidades podem tornar-se fundamentalistas. Não é necessário encará-las como uma bomba relógio do terror. É inegável, no entanto, que os temores explicitados por Jean-Claude Kaufmann (2015) em seu instigante esboço de análise com esse título têm fundamento. Diante do atentado contra o Charlie Hebdo, em janeiro de 2015, e da violência continuada do ISIS, o autor não hesita em 
afirmar que tudo começou com o processo de asserção das diferenças. Originalmente defensiva, tendo a religião como "roupagem exterior" (expressão de Kaufmann), a identidade islâmica dos jovens discriminados radicalizou-se. Da mesma forma, os oportunistas da direita se aproveitam dos medos do homem médio, não integrante de minorias, para forjar um nacionalismo racista, fazendo dos "outros" bodes expiatórios. A exacerbação desse processo seria, segundo ele, reminiscente do que os nazistas fizeram ao reinventar o ariano (Kaufmann, 2015).

Não sou tão catastrófico com relação ao CERD, mas tenho sérios temores do discurso hoje hegemônico. Ele não foi inventado por membros de órgãos de tratado, nem pelos relatores e grupos de trabalho do Conselho de Direitos Humanos. A criação tem paternidade dispersa, origem seminal em outras áreas, e é intrinsecamente associada a aspectos característicos do mundo contemporâneo. Os governos têm grande parcela de culpa. Muitos utilizam esse discurso em foros internacionais, em paralelo ao uso doméstico irrefletido. Se os Estados-partes da Convenção o quisessem, poderiam controlar os excessos dos peritos. Bastaria exigir comedimento em resoluções da Assembleia Geral, contanto que demonstrassem equilíbrio também em suas posturas. $\mathrm{O}$ medo de parecer incorreto não ajuda intenções construtivas.

Falar de inclusão no mesmo tom em que se promove a asserção diferencial das "culturas" é uma contradição inerente ao capitalismo de hoje. $\mathrm{O}$ discurso multiculturalista hegemônico, falsamente "liberal" ou "progressista", é ideologia aceitável pela competitividade econômica. O mosaico de culturas cria nichos para novas demandas. Estimula, porém, o segregacionismo, ativo ou reativo, que tende à agressividade. Com a precarização do trabalho, o desemprego encarado como fatalidade e os serviços sociais em ruínas, a criminalidade já alta se expande e a violência se banaliza. Acrescentar o ingrediente racial ou religioso é fácil. Daí aos 
fundamentalismos agressivos, às diferenças extremistas, ao terror como caminho para a salvação, o percurso é conhecido. A alternativa totalitária também.

Retomando os títulos temáticos dos dois painéis do seminário de 2015, é fácil concluir que, ao longo dos cinquenta anos da Convenção, algumas práticas foram boas, mas as lições aprendidas, muito poucas. Diante dos desafios atuais, ninguém sabe indicar o melhor caminho para seguir adiante. Todos os que estão sendo tomados no CERD, nos Estados-partes e no discurso da ONU, longe de corrigirem situações problemáticas, vêm recriando problemas ou exumando tendências negativas antes amortecidas. Talvez seja oportuno retomar a ideia de integração universalista acima da afirmação de diferenças. A integração pode ser democrática, não forçada, sem excluir diferenças flexíveis. Diferenças culturais assertivas, ao contrário, são sempre, por definição, metanarrativas específicas, totalizantes para quem as invoca.

O CERD, hoje fraco como todos os órgãos de direitos humanos, não tem como enfrentar grandes desafios. Poderia, porém, demonstrar mais atenção para os horrores imediatos, acrescentando sua voz para aquilo que sempre se tentou na área dos direitos humanos: constranger os responsáveis por violações maciças. Na conjuntura vivida, é importante que os esforços se dirijam a todos os que alimentam conflitos com apoio econômico e militar a facções antagônicas. Voluntária ou involuntariamente, tais apoios fortalecem também as sementes potenciais do terror, às vezes contra eles próprios. As guerras de facções na Síria, no Iêmen, na Líbia, com intervenções externas, já ultrapassam largamente, em duração e efeitos, as atrocidades do fim da Iugoslávia. A comemoração dos cinquenta anos da Convenção foi uma oportunidade perdida de demonstrar consciência perante esses fatores de estímulo a discriminações e massacres. Teria sido bom momento também para incentivar correção de rumos dos peritos. Para isso, é preciso ter coragem de 
enfrentar os modismos, apontar exageros, tratar com adequação a pluralidade cultural existente em todo o mundo. Assim como o discurso dos direitos humanos passou do indivíduo às culturas, ele pode, e precisa, mudar novamente, no sentido da Declaração Universal.

O direito à diferença é premissa básica de qualquer liberdade. As diferenças, contudo, não podem ser mais do que são: variações respeitáveis do humano, não sacralizações absolutas de tudo o que alguns consideram intocável. Tampouco se deve permitir a consagração de distorções, racistas e antirracistas, em nome de identidades ditas culturais. Diferenças são partes de um universal não imposto, construído gradativamente desde 1948, que a Conferência de Viena de 1993 confirmou. O universal precisa ser mantido. Sem esse objetivo bem claro, a proteção às culturas como valores em si é matéria certamente importante, da competência da Unesco, não do CERD.

Sem correções no discurso da ONU, dos Estados, das ONGs, dos movimentos sociais, das universidades, prevalecerá a sensação atual de que o sistema internacional de direitos humanos, gravemente desfocado, existe para uso dos próprios militantes, numa dimensão autista: funciona apenas para dentro, numa redoma de vidro.

A redoma é transparente. Pode ser retirada ou quebrada. Ainda nos cabe escolher.

\section{José A. Lindgren-Alves}

é cônsul geral do Brasil em Barcelona e membro, a título pessoal, do Comitê para a Eliminação da Discriminação Racial (CERD) da ONU.

\section{Bibliografia}

BAUMAN, Z. 2001. Community: seeking safety in an insecure world.

Cambridge: Polity Press.

CALDWELL, C. Affirmative action: racism's escape- or a trap. The New York Times, 23 dez. 2006. 
KAUFMANN, J.-C. 2015. Identidades: una bomba de relojería. Tradução de Anna Herrera. Barcelona: Ariel.

LINDGREN-ALVES, J. A. L. 2001. Relações internacionais e temas sociais: a década das conferências. Brasília: Funag/IBRI. . 2005. Os direitos humanos na pós-modernidade. São Paulo: Perspectiva.

. 2011. Os direitos humanos como tema global. 2. ed. São Paulo: Perspectiva.

LISBOA, A. P. Alambamento. O Globo, 9 nov. 2016. Disponível em: <http://oglobo.globo.com/cultura/alambamento-20434998>. Acesso em: 2 mar. 2017.

LYOTARD, J.-F. 1979. La condition postmoderne: rapport sur le savoir. Paris: Minuit.

MICHAELS, W. B. 2006. The trouble with diversity: how we learned to love identity and ignore inequality. New York: Metropolitan Books.

SARTORI, G. 2003. Pluralisme, multiculturalisme et étrangers. Paris: Éditions des Syrtes. 


\section{CINQUENTA ANOS DA CONVENÇÃO SOBRE A ELIMINAÇÃO DA DISCRIMINAÇÃO RACIAL: UMA APRECIAÇÃO CRÍTICA DE DENTRO}

\section{JOSÉ A. LINDGREN-ALVES}

Resumo: A Convenção Internacional sobre a Eliminação da Discriminação Racial completou 50 anos em 2015. Com base no que foi dito e omitido na principal comemoração, o autor, membro do comitê que acompanha sua implementação, faz um balanço dos avanços e das falhas propiciados por esse tratado de direitos humanos. Ao registrar fatos e elementos positivos, observa igualmente impasses e problemas causados pelas obsessões ditas politicamente corretas do discurso contemporâneo. Longe de superar as discriminações etnorraciais, essas posturas artificiais dão munição tanto aos militantes radicais de minorias que, sem objetivo definido, rejeitam a integração, quanto ao "nacionalismo" etnocêntrico crescentemente racista das maiorias. O discurso pode ser corrigido, desde que todos os atores envolvidos tomem consciência de tais defeitos.

Palavras-chave: Convenção; Racismo; Minorias; Fundamentalismo; Terror; Discurso Politicamente Correto.

\section{FIFTY YEARS OF THE CONVENTION ON THE ELIMINATION OF RACIAL DISCRIMINATION: A CRITICAL APPRAISAL FROM INSIDE}

Abstract: The International Convention on the Elimination of Racial Discrimination became 50 years old in 2015. Based on what was stated and omitted in the main commemoration, the author - a member of the committee in charge of monitoring its implementation - evaluated both the advancement and the failures of that human rights treaty. While recording positive achievements, he equally noted the deadlocks and risks caused by so-called politically correct 
obsessions in the contemporary discourse. Far from overcoming ethnic and racial discriminations, such artificial attitudes give ammunition to minority radicals who aimlessly refuse integration, as well as to the increasingly racist "nationalism" of ethno-centric majorities. This speech can be changed, provided all the involved actors are conscious of its defects.

Keywords: Convention; Racism; Minorities; Fundamentalism; Terror; Political Correctness.

Recebido: 17/11/2016 Aprovado: 16/12/2016 